\title{
THE JUDGMENT OF PONTIUS PILATE: A CRITIQUE OF GIORGIO AGAMBEN
}

\author{
D. L. DUSENBURY \\ Postdoctoral Fellow, De Wulf-Mansion Centre, Institute of Philosophy, University of Leuven, Belgium
}

\begin{abstract}
In Pilate and Jesus, Giorgio Agamben argues that Pontius Pilate never formally condemned Jesus of Nazareth. "The traditional interpretation of Jesus' trial ... must be revised," he urges, because "there has not been any judgment in a technical sense." In Agamben's telling, Pilate's non-judgment is the original truth of Jesus's death that has been covered over by tradition. This is an intriguing hypothesis, but Agamben's use of sources in arguing it is highly irregular. This article offers a critique of the legal and philological argumentation of Pilate and Jesus. In the process, it revisits an ancient-and still actual-controversy surrounding the Roman trial of Jesus and demonstrates that Pilate did sentence Jesus, pro tribunali, to death on a cross.
\end{abstract}

KEYWORDS: political theology, Giorgio Agamben, Roman law, New Testament, Pontius Pilate, Jesus of Nazareth, Lactantius, Hugo Grotius

Pilate seeks tenaciously to avoid the pronunciation of a verdict. Even at the end, when he yields to the tumultuous insistence of the Jews, the prefect does not, as we will see, pronounce a sentence.

- Giorgio Agamben

Pilate gave sentence.

- Luke 23:24

\section{INTRODUCTION}

With its nineteen numbered sections and seven "glosses," all of which only fill some sixty pages, Giorgio Agamben's Pilate and Jesus is an opuscule. Nor would the Italian philosopher object to this diminutive. In a candid piece he wrote for La Stampa after Pilato e Gesú appeared, ${ }^{\mathrm{r}}$ Agamben called it a libretto - which is to say, not a libro - and admitted to having written it in several "frenetic months." 2 The haste shows. Nevertheless, this libretto makes a dense and provocative addition to Agamben's influential oeuvre.

I Agamben, Pilato e Gesú, 2nd edition (Rome: Nottetempo, 20I4); Agamben, Pilate and Jesus, trans. Adam Kotsko (Stanford: Stanford University Press, 2015).

2 Agamben, "Il fascino discreto di Ponzio Pilato," La Stampa (2013), 30-3 I. 
Agamben's method in Pilate and Jesus is characteristically philological or, more loosely, "genealogical" and "archaeological" (à la Friedrich Nietzsche and Michel Foucault). ${ }^{3}$ In a series of books, he has attempted to theorize contemporary legal, political, and economic complexes on the basis of legal, philosophical, and ritual complexes that link antiquity to the present. ${ }^{4}$ Or as Agamben expressed it in his fullest statement on method, The Signature of All Things:

My investigations ... have an archaeological character, and the phenomena with which they deal unfold across time and therefore require an attention to documents and diachrony that cannot but follow the laws of historical philology. Nevertheless ... [they seek to make] the inquirer's present intelligible, as much as the past. 5

In Pilate and Jesus, one of the most recent displays of Agamben's method, ${ }^{6}$ the appearance of Jesus before Pontius Pilate becomes "an allegory of our time." 7 But what could this mean?

Unlike the heterodox Marxist philosopher Ernst Bloch, who wrote in I9I6 that "our modern age is burdensome" because "Easter and Pentecost seem like one long Good Friday, like merely the insubstantial knowledge that the Redeemer has died"; 8 Agamben now writes, a hundred years on, that modernity is unfurling "in a state of permanent crisis" because Pontius Pilate "has not handed down a legitimate judgment." 9 Our period is not afflicted by a post-Christian malaise, brought on by the conviction that the Redeemer is dead-that is, is not resurrected. Rather, late modernity is traumatized by a latent sense that the Redeemer has died-and was never sentenced.

This is Agamben's thesis in Pilate and Jesus: Pilate never formally, pro tribunali, condemned

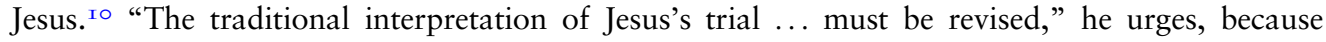
"there has not been any judgment in a technical sense." II Pilate's non-judgment is the original truth of Jesus's death which has been "covered over and neutralized by tradition." I2

3 And for the marked influence of Enzo Melandri on Agamben's concept of "philosophical archaeology," see Agamben, The Signature of All Things: On Method, trans. Luca D'Isanto with Kevin Attell (New York: Zone, 2009), 96-107.

4 Among his more recent contributions are Agamben, The Kingdom and the Glory: For a Theological Genealogy of Economy and Government, trans. Lorenzo Chiesa with Matteo Mandarini (Stanford: Stanford University Press, 20II); Agamben, The Sacrament of Language: An Archaeology of the Oath, trans. Adam Kotsko (Stanford: Stanford University Press, 20I I); Agamben, Opus Dei: An Archaeology of Duty, trans. Adam Kotsko (Stanford: Stanford University Press, 2013); Agamben, The Highest Poverty: Monastic Rules and Form-of-Life, trans. Adam Kotsko (Stanford: Stanford University Press, 2013).

5 Agamben, Signature of All Things, 3 I-32.

6 More recent is Agamben, Stasis: Civil War as a Political Paradigm, trans. Nicholas Heron (Edinburgh: Edinburgh University Press, 2015).

7 Agamben, Pilate and Jesus, 57.

8 Bloch, The Spirit of Utopia, trans. Anthony A. Nassar (Palo Alto: Stanford University Press, 2000), I68. Note that although the first edition of Bloch's Geist der Utopie is dated 1918, most of the book was drafted in the years I9I 5-I 6 .

9 Agamben, Pilate and Jesus, 57.

Io The contrast could not be sharper with Bloch's materialist reading of Jesus's trial. Bloch has nothing but contempt for what he reads as the "noblesse" of Pilate and the "defeatism" of Jesus, particularly in John's trial narrative. "It is incompatible with the courage and dignity of Jesus," Bloch decides, "that he should use such defeatist words in front of Pilate." (He has in mind especially John I 8:36: "My kingdom is not of this world.”) Bloch is adamant that "the Romans convicted Jesus as a revolutionary" (emphasis added), while he cannily appeals to Jesus's titulus as evidence of a Roman sentence. Ernst Bloch, Atheism in Christianity: The Religion of the Exodus and the Kingdom, trans. J. T. Swann (London: Verso, 2009), I I 2-23. For a discussion of biblical translations used, see footnote 38 .

I I Agamben, Pilate and Jesus, 48-49 (emphasis added).

I2 Agamben, Signature of All Things, I05. 
Obviously, this is a juridical thesis. And one of its consequences, according to Agamben, is that the trial of Jesus was not a valid trial according to Roman law, but rather the "semblance of a trial." ${ }^{3}$ Agamben argues this on the grounds that none of the evangelists report "the pronouncement of a clear sentence of conviction." ${ }^{4} 4$ Perhaps, on this account, the Roman prefect's infamous hand-washing could be regarded less as hypocritical, than as properly symbolic. ${ }^{\mathrm{I}}$ Pilate could wash his hands of Jesus because he would never condemn Jesus.

On the face of it, this thesis is not implausible. In his Embassy to Gaius, Philo of Alexandria complains that Pilate frequently ordered "extrajudicial killings," ${ }^{\prime 6}$ and had acquired a reputation for "supremely grievous cruelty." ${ }^{17}$ On the basis of this non-Christian testimony, it could even be predicted that Pilate would have crucified Jesus without a trial-or, as Agamben prefers, after "a trial without a judgment" (un processo senza giudizio). ${ }^{\mathrm{I}}$

And if Agamben's juridical thesis is correct, the theological consequences could prove to be fundamental, since according to Agamben, "a trial without judgment" is "not properly a trial" I9; and since, according to Dante's Monarchy (a work that Agamben treats as emblematic of Christian political theology), ${ }^{20}$ a capital sentence that is not imposed by a judge is not a "punishment" (punitio) at all, but rather an "injury" (iniuria). ${ }^{21}$ This would seem to accord with the most general definition of "injury" in the Corpus Iuris Civilis as "whatever is not done by right." 22

I 3 Agamben, Pilate and Jesus, 5I (emphasis added).

I 4 Ibid., 32 (emphasis added).

I 5 Yet Agamben, strangely, only sees a "hypocritical scrupulousness" in Pilate's hand-washing. Agamben, Pilato $e$ Gesú, Io (author's translation).

I6 Philo's Greek speaks directly to Agamben's thesis in Pilate and Jesus. With the phrase I translate here as "extrajudicial killings," Philo criticizes Pilate for having put to death Roman subjects in Judaea "without a trial”-or, more literally, "without a judgment" (tous akritous ... phonous). In Pilate and Jesus, Agamben argues precisely that Pilate handed Jesus over to be crucified "without a judgment" (akritos).

This Philonic passage elicits a comparison with two Lukan sentences:

"Is it lawful for you," Paul challenges a tribune in Jerusalem, "to scourge a man who is a Roman citizen and has not been sentenced [akatakriton; Vulgate indemnatum]?” (Acts 22:25)

And again, this is Paul's challenge to a Roman officer: "They have beaten us publicly, without our having been sentenced [akatakritous; Vulgate indemnatos], men who are Roman citizens.” (Acts I6:37)

These are the only New Testament occurrences of akatakritos-a peculiarly Lukan term that seems to carry the same sense as Philo's akritos.

Unlike Paul, of course, Jesus was not a civis Romanus. Paul had a citizen's panoply of rights; Jesus did not. The crucial point for us, however, is that Luke clearly had a term at his disposal-"unsentenced" or "uncondemned" (akatakritos) - to characterize Jesus's death if Pilate had sent him to the cross without having sentenced him. The origins of this procedural terminology in classical Athenian law are sketched by Edwin M. Carawan, "Akriton Apokteinai: Execution without Trial in Fourth-Century Athens," Greek, Roman and Byzantine Studies 25, no. 2 (I984): III-2I. And it is worth noting that neither the Lukan term akatakritos nor the Philonic term akritos occurs in the New Testament-or, to my knowledge, in any early Christian text-apropos of Jesus's death.

Philo Judaeus, Legatio ad Gaium 302; Philo, The Embassy to Gaius, ed. with trans. F. H. Colson (Cambridge, MA: Harvard University Press, I97I), I 52-53 (translation modified).

I8 Agamben, Pilate and Jesus, 49; Agamben, Pilato e Gesú, 67.

I9 Agamben, Pilate and Jesus, 49.

20 This, despite the fact that Dante's treatise was burned publicly - on the pope's orders - in I 329 .

2 I Dante, Monarchia 2.II.4-5; Dantis Alagherii De Monarchia libri 3, ed. Ludwig Bertalot (Florence: Leon S. Olschki, I920), 72.

22 Institutiones 4.4; Justinian's “Institutes," ed. Paul Krueger, trans. Peter Birks and Grant McLeod (London: Duckworth, 1987), I26-27. Difficulties arise, however, as soon as we consider the special definitions of iniuria set out in Institutiones 4.4 (where any unjust verdict constitutes iniuria: the evangelists of course regard Pilate's 
But what would it mean if Jesus's death had no legal status? If Jesus had not been condemned to the "ultimate punishment" by a Roman prefect but merely killed hors la lo $i$ with the prefect's connivance? According to Dante, at least, the theological significance of this irregularity would be catastrophic. He reasons that if "Adam's sin was not punished in Christ" - that is, by a penalty exacted after a solemnly concluded Roman trial-all of humankind "would still be 'the children of wrath." ${ }_{23}$ And what would it mean for us still, if Jesus's trial had reached no formal conclusion? That is to say, if-as Agamben claims - the trial of Jesus is, "in a certain way ... always under way"? 24

These questions, posed by Agamben, are genuinely interesting. His use of sources in posing and resolving them, however, is at times high-handed, and at others - to all appearances - underhanded. Since Agamben takes "attention to documents" as a methodological ground rule; professes to "follow the laws of historical philology"; 25 and undertakes in Pilate and Jesus to "carefully evaluate every detail of the chronicle of [Jesus's] confrontation [with Pilate]," ${ }^{26}$ this sort of philological indiscipline can only drastically undermine his conclusions.

Agamben's legal-philosophical writings have seen a decade or so of intensely politicized and often exotic appropriation. They have occasionally been the object of polemics. Yet they have least frequently met with rigorous criticism on their own terms. It is, thus, precisely a philological critique of the philological arguments made in Pilate and Jesus that I offer in this article. The result is a demonstration that Pilate did sentence Jesus to death on a Roman cross.

\section{THE STRUCTURE OF AGAMBEN'S TEXT}

On the surface, Agamben's text has no structure - apart from its division into nineteen numbered (but untitled) sections, and seven unnumbered (and untitled) sections. The seven unnumbered sections of the text are best treated as their rubric suggests: they are Agamben's "glosses." The reader can use them to clarify or amplify the meaning of his core, numbered sections.

But while Agamben's numbered sections carry no titles and exhibit no obvious order, I suggest that they can nevertheless be distributed into five definite-if not always discrete-groupings:

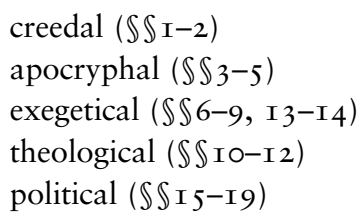

As these groupings do not contribute equally to the interpretive base or argumentive arc of Pilate and Jesus, in my discussion I therefore treat them accordingly.

In Agamben's introductory creedal grouping, I identify a pair of clear implications regarding Pontius Pilate's place in the Creed-neither of which holds up under close inspection. In the

verdict as unjust, even if the trial is procedurally valid); the Lex Aquilia at Institutiones 4.3 (where it is never iniuria to kill a latro, that is, a "bandit" or "rebel": Pilate decrees that Jesus should be crucified between two latrones, and he sentences him as a rebel); and the Lex Julia at Digesta 48.7 (where only Roman citizens can suffer judicial iniuria: Jesus is, of course, not a Roman citizen). 
apocryphal grouping that follows, we will see that Agamben makes substantial use of only a single passage in a single extra-canonical text-a fourth-century Acts of Pilate-and that this passage contradicts the juridical thesis of Pilate and Jesus.

The question of the irregularity of Jesus's trial only comes to the fore in Agamben's exegetical grouping, but it remains decisive for the remainder of his text. The core section of this grouping is $\mathbb{7}$, which is also the core section of Pilate and Jesus. This is where Agamben sketches his interpretation of Jesus's Roman trial in seven "scenes," ${ }^{27}$ privileging the trial narrative in John's gospel. ${ }^{28}$ Yet Agamben's decisive claims are not made in $\$ 7$. First, in $\$ 6$, he claims that none of the gospels reports a Roman judgment expressis verbis; and second, in $\mathbb{I} \mathrm{I}_{3}$, that Pilate "hands over" Jesus without having sentenced him. Both claims set the argumentive arc of Pilate and Jesus, and both prove to be false. With these claims discredited, the theological and political groupings of Pilate and Jesus lose their force.

In a historical excursus, I trace the thesis of Pilate's non-judgment back to the Divine Institutes of Lactantius, a fourth-century Roman courtier; and then outline the refutation of the Lactantian tradition by the celebrated seventeenth-century Dutch legist, Hugo Grotius. It is not without interest to see how the thesis of Pilate and Jesus is dismantled, avant la lettre, by the leading international lawyer of the early modern period.

I conclude with a very brief critique of Agamben's general theory of judgment, as he presents it in Pilate and Jesus.

\section{CREEDAL GROUPING: THE PRIMITIVE CENTRALITY OF PONTIUS PILATE}

I once overheard a joke in a Budapest establishment, which I believe is Hungarian, or at least Middle-European: "I made it in like Pilate made it into the Creed." This captures the sense of improbability - or even, on the face of it, impropriety - that Agamben uses to open his text. The only name to appear in the core profession of Christian belief, beside those of Mary and Jesus, is that of a pagan, Roman official-an idolater. ${ }^{29}$ Christians are still, to this day, confessing that they believe in Pontius Pilate. $3^{\circ}$ Why is this?

Agamben first points out that Pilate is not named in the creed promulgated by the Council of

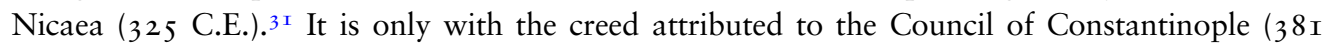
C.E. $)^{32}$ that a conciliar creed represents Jesus as having been "crucified for us under Pontius

27 The Johannine trial can be differently punctuated. Josef Blinzler, for instance, sees six distinct scenes (sechs Einzelszenen) where Agamben sees seven. Blinzler, Der Prozess Jesu. Das jüdische und das römische Gerichtsverfahren gegen Jesus Christus auf Grund der ältesten Zeugnisse dargestellt und beurteilt (Regensburg: Friedrich Pustet, I955), I35.

28 Agamben, Pilate and Jesus, 15.

29 For an argument that Pilate was "a prefect determined to promote a form of Roman religion in Judaea," see Joan E. Taylor, "Pontius Pilate and the Imperial Cult in Roman Judaea," New Testament Studies 52, no. 4 (2006): $555^{-82}$.

30 It has recently been argued that Pilate administered Judaea from I $7 / 18$ to $36 / 37$ C.E., but the accepted dates are still 26 to 36 C.E. See David W. Chapman and Eckhard J. Schnabel, The Trial and Crucifixion of Jesus: Texts and Commentary, Wissenschaftliche Untersuchungen zum Neuen Testament 344 (Tübingen: Mohr Siebeck, 2015), I $58-63$.

3 I "Symbolum Nicaenum," in Enchiridion Symbolorum definitionem et declarationem de rebus fidei et morum, ed. Heinrich Denzinger, rev. Adolfus Schönmetzer, 32nd ed. (Barcelona: Herder, I963), 52-53.

32 The Council of Constantinople sat from July 9 to 30,38 I. Conciliorum Oecumenicorum Decreta, ed. Giuseppe Alberigo et al. 3rd ed. (Bologna: Istituto per le Scienze Religiose, 1973), 23. 
Pilate." ${ }_{33}$ Agamben uses this contrast-Pilate's absence in the 325 creed, and his presence in the 38 I creed - to structure what I call the creedal grouping of Pilate and Jesus $(\mathbb{S} \mathbb{I}-2)$.

In $\ \mathrm{I}$, Agamben writes that Pilate's name "was added in 38I by the Council of Constantinople, by all evidence in order to ... fix the historical character of Jesus' passion chronologically." 34 In $\mathbb{2}$, he returns to this accretion, now asking why "the Fathers assembled at Constantinople preferred Pilate to Tiberius, the prefect [of Judaea] ... to Caesar." 35 Agamben then asks: Would it not have been more natural for the Constantinopolitan Creed to state that Jesus was crucified "under Tiberius" (sub Tiberio), much as Dante's Vergil was born “under Julius" (sub Julio)? ${ }^{6}$ He then-correctly-suggests that Tiberius would be the more logical reference here, if "the historical character of Jesus' passion" were all that concerned the Council of Constantinople. In support of this, Agamben cites Luke 3:I,37 where John the Baptist begins to preach "in the fifteenth year of the reign of Tiberius Caesar." ${ }^{8} 8$

On the basis of this set of clear implications-Agamben presents them as $(\alpha)$ that Pilate only surfaced in creedal formulas in the year $38 \mathrm{I}$, and $(\beta)$ that Tiberius Caesar would have been the most logical "pagan" to have figured in the creed of $38 \mathrm{I}$-Agamben proposes a vague, tentative reason for Pilate's appearance in the Constantinopolitan Creed: "It is possible that over [the Council's] undoubted chronographic intention there prevailed the importance that the figure of Pilate has in the narrative of the Gospels." 39 This conjecture permits Agamben to then aestheticize and psychologize the figure of Pilate in the remainder of $\mathbb{\$} 2$.

"One can say," Agamben goes on to say, "that Pilate is perhaps the only true 'character' of the Gospels." $4 \circ$ By this, he means that it is only with Pilate, and over the course of Jesus's trial, that "the evangelists reveal ... something like the intention to construct a character, with his own psychology and idiosyncrasies." ${ }^{\mathrm{I}}$ Yet bypassing the theological tradition entirely, a single page of a I 920 Soviet-suppressed novel by Sigizmund Krzhizhanovsky serves to discredit this notion. For Jesus is himself, of course, an artfully realized character in the gospels. Krzhizhanovsky, in passing, registers the uncanny effect of Jesus's silences in the gospels. These pauses are so pregnant, and so singular-says Krzhizhanovsky - that one could arrange them to compose a "Gospel according to Silence." ${ }^{2} \mathrm{He}$ is right. And one such silence occurs during Jesus's interrogation by Pilate, "so that the governor was greatly amazed." 43

\footnotetext{
33 "Symbolum Constantinopolitanum," in Enchiridion Symbolorum, 66-67.

34 Agamben, Pilate and Jesus, I.

35 Ibid., 2.

36 Ibid.; Agamben, Pilato e Gesú, 8-9. Agamben's reference here is to Inferno I.70, where Vergil introduces himself to the poet, saying, "I was born sub Julio." The Inferno of Dante: A New Verse Translation, trans. Robert Pinsky, annot. Nicole Pinsky (New York: Farrar, Straus and Giroux, I994), 4. As Agamben surely knows, Dante's late medieval chronography is far from exemplary. Vergil was born in 70 B.C.E. - under the Republic, not sub Julio. Agamben, Pilate and Jesus, 2.

38 I often quote the Douay-Rheims (D-R) translation of the New Testament-and always the Vulgate-from The Vulgate Bible, vol. 6, The New Testament, Douay-Rheims Translation, Dumbarton Oaks Medieval Library 2I, ed. Angela M. Kinney (Cambridge, MA: Harvard University Press, 20I3). But I have, with some frequency, preferred the New Revised Standard Version (NRSV) of The Book of Common Prayer... According to the Use of The Episcopal Church (New York: Oxford University Press, 2007). Note that I have at places silently modified the English of both translations in light of the Greek original. Agamben, Pilate and Jesus, 2-3 (emphasis added).

40 Ibid., 3; Agamben, Pilato e Gesú, го.

4 I Agamben, Pilate and Jesus, 3.

42 Krzhizhanovsky, The Letter Killers Club, trans. Joanne Turnbull and Nikolai Formozov (New York: New York Review Books, 20I2), 47-5I, esp. 50-5I.

Matthew 27:I4.
} 
It is unnecessary to analyze Agamben's literary intuitions, however, for when we turn to preNicene creed-like formulas it immediately becomes evident that the Council of Constantinoplecontra Agamben's $(\alpha)$-merely formalized Pilate's place in a host of pre-Nicene formulas.

Before even turning to these pre-Nicene formulas, we should note that Luke 3:I names Pontius Pilate. Now, this is the verse that Agamben cites in support of his notion that Tiberius had a more logical claim than Pilate upon the Creed.44 Yet this is how Luke introduces the figure of John the Baptist: "in the fifteenth year of the reign of Tiberius Caesar, Pontius Pilate being governor of Judaea." In his only reference to Christ, Tacitus uses comparable phrasing. "During the rule of Tiberius," we read in the Annals, Jesus was crucified "by sentence of the procurator Pontius Pilatus." 45 And similarly, Justin Martyr writes that Jesus was "crucified under Pontius Pilate, procurator of Judaea, in the times of Tiberius Caesar." 46

Notwithstanding this common form of dating under the emperors - that is, of dating by emperors' regnal years-Luke 3:I indicates how Agamben has misconstrued both Pilate's presence and Tiberius's absence in the Constantinopolitan Creed. For Agamben simply assumes that Pilate's name is a chronological index in the Creed, when it is, rather, a jurisdictional index. What Agamben takes to be the Creed's historical line is, instead, a juridical line. 47

Pontius Pilate held the office of "prefect of Judaea" (praefectus Judaeae). $4^{8}$ For a trial that was held in Judaea circa 30 C.E., ${ }^{49}$ a reference to Pilate happens to be chronologically more serviceable than a reference to Tiberius-since Tiberius ruled from I 4 to 37 , whereas Pilate only held his prefectship from 26 to 36 . But this is immaterial. Dates in the first centuries C.E. were indexed by emperors' regnal years - not by provincial officials' careers. The Creed names Pilate because this is institutionally and jurisdictionally more precise than a reference to Tiberius.

The emperor had isolated himself on Capri beginning in the year 25, and Tiberius's debauchery there had resulted - as Suetonius relates - in his near-total neglect of Roman Palestine. ${ }^{\circ}$ By way of contrast, Pilate occupied a heavily fortified palace at Caesarea Maritima on Israel's coastline. He is only ever named-in Christian and non-Christian sources alike ${ }^{5}-$ in connection with his tenure as

44 Agamben, Pilate and Jesus, 2.

45 Tacitus, Annales I 5.44; Tacitus, The Annals. Books XIII-XVI, ed. with trans. John Jackson (London: William Heinemann, I98I), 282-83.

46 Justinus, Apologia I I 3 ; Justinus, S. Iustini Philosophi et Martyris Opera, 2 vols., ed. Johann Carl Theodor Otto (Jena: Frider. Mauke, I 847), I:33-35; Justin Martyr, “The First Apology of Justin,” in The Ante-Nicene Fathers, vol. I, The Apostolic Fathers: Justin Martyr, Irenaeus, ed. and trans. Alexander Roberts et al. (Edinburgh: T \& T Clark, n.d.), I 66.

47 I argue the same point somewhat more sharply in an essay that was written when this article was in press: Dusenbury, "Pilate Schemes," TLS. The Times Literary Supplement 5895, March 23, 2016, I5, https:/www. the-tls.co.uk/articles/private/pilate-schemes/.

48 According to an inscription on a limestone block that was recovered at Caesarea Maritima in Israel, in I96I, where [PO]NTIVS PILATVS is titled the [PRAEF]ECTVS IVDA[EA]E. For a reconstructed text, translation, and level-headed interpretation of this "architectural dedication dating to A.D. 3I-36," see Chapman and Schnabel, Trial and Crucifixion of Jesus, 165-67.

49 The scholarly consensus is that the crucifixion occurred on April 7, 30 C.E. But Helen Bond has very recently argued that "all that the evidence allows us to claim is that Jesus died ... between 29 and 34 CE." Helen K. Bond, "Dating the Death of Jesus: Memory and the Religious Imagination," New Testament Studies 59, no. $4(20 \mathrm{I} 3): 46 \mathrm{I}-75$.

50 Suetonius, Tiberius 4I-45; "Tiberius," in Suetonius I, ed. with trans. J. C. Rolfe (Cambridge, MA: Harvard University Press, I998), 368-75.

5 I Chapman and Schnabel, Trial and Crucifixion of Jesus, I96 ("Tacitus mentions Pontius Pilatus only because he wants to provide the historical context for the execution of Jesus ... which he presents as the result of a legally correct trial.”). 
"the highest Roman official in Judea." ${ }^{2}$ Whereas Tiberius's jurisdiction never ceased to extend-in Luke's phrase-to "all the world," ${ }_{33}$ Pilate's strictly coincided with the imperial province within which Jesus lived and died.

Contra Agamben's $(\beta)$, then, it is perfectly logical for Pontius Pilate to figure in the Constantinopolitan Creed. The name "Pilate" succinctly accounts for the crucifixion of Jesus-a Roman punishment ${ }^{54}$-outside the walls of Jerusalem. For this execution, there is no need to reference Tiberius. We find a subtle confirmation of this in Luke 20:20, where it is only the Roman prefect who matters when the evangelist relates how the high-priestly court in Jerusalem sought to "hand Jesus over to the jurisdiction (archē) and authority (exousia) of the governor." Why would Pilate's appearance in the Creed not be determined by his "jurisdiction and authority" in Roman Judaea? And similarly, in Luke I3:I,55 when Luke alludes to certain "Galileans whose blood Pilate had mingled with their sacrifices" at Jerusalem, there is no reference to Tiberius. This is because the name "Pilate" suffices to account for the deaths of these Galileans in Jerusalem. ${ }^{56}$

And this is why it is primarily Pilate - the prefect of Judaea - who is named in a great number of primitive Christian formulas which recollect Jesus's death. The first of these is incorporated into the New Testament. At I Timothy 6:I3, the letter's recipient is charged to keep the faith "in the presence of God, who gives life to all things, and of Christ Jesus, who in his testimony before Pontius Pilate made the good confession." This passage goes unnoticed by Agamben, but in his study of the early Christian creeds, J. N. D. Kelly remarks that the "creed-like character" of this passage "leaps at once to the eye." 57

The apostolic centrality of Jesus's suffering "under Pontius Pilate" is similarly attested by Peter's sermon in Acts 3, where Jesus is "delivered up ... before the face of Pilate" and then crucified (3:I3-I5); by the kerygmatic prayer of Peter and John in Acts 4, which begins (much like the Symbolum Apostolicum), "Lord, you are he that made heaven and earth," before reciting how "Herod and Pontius Pilate, with the Gentiles and peoples of Israel" had conspired against the Christ (4:24-30); and finally-still within the canonical Acts-by Paul's sermon in the synagogue at Antioch, where he states that the Judaic "rulers" of Jerusalem had "asked Pilate to have him killed" (I3:27-28).

It is doubtless this litany of apostolic references to Pilate that echoes through Ignatius of Antioch's early Greek epistles (ca. I07), where we see that Jesus's passion and resurrection occurred "in the time of the governorship (bēgemonias) of Pontius Pilate," ${ }_{58}^{8}$ and that Jesus was "truly nailed

52 Ibid., I6I.

53 Luke 2:I. Or so the Vulgate, at least, referring to Augustus reads "edictum a Caesare Augusto ut describeretur universus orbis.” The Greek reads “pasan tèn oikoumenèn.” See Kurt Aland, Synopsis Quattuor Evangeliorum. Locis parallelis evangeliorum apocryphorum et patrum adhibitis (Stuttgart: Württembergische Bibelanstalt, I964), Io.

54 According to Mishnah Sanhedrin 7.I, the only methods of execution permitted under Judaic law are stoning, burning, "slaying" (that is, beheading), and strangling. See Paul Winter, On the Trial of Jesus, Studia Judaica: Forschungen zur Wissenschaft des Judentums I (Berlin: Walter de Gruyter, I96I), 70; E. J. Bickerman, "Utilitas Crucis: Observations on the Accounts of the Trial of Jesus in the Canonical Gospels," in Studies in Jewish and Christian History: A New Edition in English Including The God of the Maccabees, Arbeiten zur Geschichte des Antiken Judentums und des Urchristentums 68, ed. Amram Tropper (Leiden: Brill, 2007), 2:784.

55 Harold W. Hoehner, Herod Antipas, Society for New Testament Studies Monograph Series I7 (Cambridge: Cambridge University Press, I972), I74-75.

56 Bond, Pontius Pilate, I94-96.

57 Kelly, Early Christian Creeds, 20.

58 Ignatius, Epistola ad Magnesios I I.I; "Ignatius to the Magnesians," in The Apostolic Fathers, 2 vols., ed. with trans. Kirsopp Lake (London: William Heinemann, I9I2), I:208-9. 
to a tree in the flesh for us under Pontius Pilate." ${ }_{59}$ Turning to one of the earliest Latin fathers, Justin Martyr's First Apology (ca. I 50) ${ }^{60}$ contains a kerygmatic invocation of "Jesus Christ, who was crucified under Pontius Pilate," ${ }^{6 \mathrm{I}}$ and reports a baptismal liturgy in which the baptizand is washed "in the name of Jesus Christ, who was crucified under Pontius Pilate." ${ }_{22}$ Again, in Justin's Dialogue with Trypho, we find a formulaic passage which rehearses how the Son of God came to be "crucified under Pontius Pilate."63

References to Pilate continue to surface in the third and fourth centuries. For instance, in a creedal formula that Tertullian recites as the only immutable "law of faith," we read that Jesus was "crucified under Pontius Pilate." 64 Hippolytus of Rome records a Latin formula in which Jesus is "crucified under Pontius Pilate." ${ }_{55}$ And Marcellus of Ancyra preserves an early Greek formula according to which Jesus is "crucified under Pontius Pilate." 66

These testimonies place it out of question that Pilate's name is a recurring, even a routine, element of pre-38I liturgical and creedal formulas in Greek and in Latin. ${ }^{67}$ Contra Agamben's $(\alpha)$, then, Pilate's appearance in the Constantinopolitan Creed of $38 \mathrm{I}$ is neither novel nor mystifying. $\mathrm{He}$ is recollected as the Roman prefect of Judaea at the time of Jesus's death on a cross. The creed's wording thus proves to be precise. Jesus was crucified under Pontius Pilate-and not in the time of Pontius Pilate.

\section{APOCRYPHAL GROUPING: "HOW THOSE WHO TELL THE TRUTH ARE JUDGED"}

Pilate does not figure in the Constantinopolitan Creed because he intrigued the bishops of the Council of Constantinople. Still, there is no denying that early Christians were fascinated by Pilate's psychology - or perhaps better, by the question of his "conscience" (conscientia). ${ }^{68}$ The reason for this fascination is, arguably, simple.

According to Tacitus's Annals, Jesus was put to death "by sentence of the procurator Pontius Pilatus." ${ }^{69}$ And according to Josephus's Judaic Antiquities, Pilate "condemned [Jesus] to the cross"

59 Ignatius, Epistola ad Smyrnaeos I.2; "Ignatius to the Smyrnaeans," in Lake, Apostolic Fathers, I:252-53 (translation modified).

60 Arguably written as early as 139 C.E. P. Lorraine Buck, "Justin Martyr's Apologies: Their Number, Destination, and Form," Journal of Theological Studies 54, no. I (2003): 45-59, at 55.

6I Justinus, Apologia I I3; Justinus, S. Iustini Philosophi et Martyris Opera, I:33-35; Justin Martyr, "The First Apology of Justin," I 66.

62 Justinus, Apologia I 6I; Justinus, S. Iustini Philosophi et Martyris Opera, I:I47; Justin Martyr, "The First Apology of Justin,” I83.

63 Justinus, Dialogus cum Tryphone, 85; Justin, S. Iustini Philosophi et Martyris Opera, I:293; Justin Martyr, "The First Apology of Justin,” 24I.

64 Tertullianus, De Virginibus Velandis I; Patrologia Latina, 22I vols., ed. Jacques-Paul Migne (Paris, I844-I864), 2:889; Tertullian, "On the Veiling of Virgins," Tertullian, Part Fourth; Minucius Felix; Commodian; Origen, parts first and second, vol. 4, The Ante-Nicene Fathers, ed. and trans. Alexander Roberts et al. (Edinburgh: T \& T Clark, n.d.), 27.

65 Enchiridion Symbolorum, 20.

66 Ibid., 2I.

67 Kelly, Early Christian Creeds, I 49.

68 Egidio Forcellini et al, Totius Latinitatis Lexicon, 6 vols. (I 864-I926; I940; repr. Bologna: Arnaldo Forni, I965), I:795-96, s.v. "conscientia."

69 Tacitus, Annales I 5.44; Tacitus, The Annals. Books XIII-XVI, 282-83. 
after he had been formally "indicted" 70 by the high-priestly court in Jerusalem. ${ }^{1 \mathrm{I}}$ Yet according to the canonical gospels, Pilate yielded to the high-priestly indictment, and ordered the crucifixion of Jesus, without being persuaded by that indictment. ${ }^{72} \mathrm{He}$ crucified a man he held to be innocent.

On this point there is no need to harmonize the canonical gospels. In all of the Synoptic accounts, Pilate challenges Jesus's accusers: "What evil has he done?" 73 And in Luke and John alike, he protests that he has found "no cause" to condemn Jesus. ${ }^{74}$ The prefect's incredulity is most explicitly stated in Luke 23, where he denies that his investigation has sustained the charges of sedition. "Having examined him," Pilate says, "I find no cause in this man." 75 This is obviously intended to read as a formal protestation of Jesus's innocence. Nevertheless, shortly after this protest, Luke reports that Pilate "gave sentence" 76 or "gave his verdict," 77 so that it was on the prefect's decree that Jesus was put to death-flanked by "bandits" or "rebels" 78 - outside of Jerusalem.

This is the tragic interest of Pilate's psychology in the canonical gospels: he declares Jesus to be innocent, but he orders the crucifixion. In terms of Aristotle's Poetics, Pilate kills Jesus like Medea kills her children: consciously. 79 The Roman prefect is neither crazed nor deceived. And because of this, the question-however misdirected-can be raised: is Pilate's decision to crucify the Son of God an act of consummate impiety (since Jesus is not only innocent but "the light of the world") $8 \circ$ or a sign of reluctant piety (since Jesus, nevertheless, "must be lifted up" for the salvation of the world) ${ }^{\text {? }}{ }^{8 \mathrm{I}}$ It is this uncertainty that inspires a colorful sub-genre of early Christian texts that embellish the Roman prefect's life and afterlife-a convoluted mass of traditions that J. K. Elliott has dubbed a "Pilate cycle." 82

70 For the classical specificity of endeixis, see Douglas M. MacDowell, The Law in Classical Athens (Ithaca: Cornell University Press, I978), 57-6r. Note also the definitions listed at Henry George Liddell and Robert Scott, $A$ Greek-English Lexicon, rev. Henry Stuart Jones, with Roderick McKenzie et al. (Oxford: Oxford University

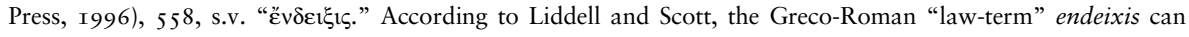
denote the "laying of information against one who discharged public functions for which he was legally disqualified.” This is of course the crime designated on Jesus's titulus: he is crucified as a pretender to Israel's throne.

7 I Josephus, Antiquitates Judaicae I 8.63-64.

72 Mark I 5:IO $\approx$ Matthew 27:I 8 . I use two symbols throughout this essay to indicate cases in which the wording of a verse or phrase in one gospel is identical $(=)$ or nearly identical $(\approx)$ to one in the same or another gospel.

73 Mark I 5:I 4; Matthew 27:23; Luke 23:22.

74 Luke 23:4, 23:I3-I 5, 23:22; John I 8:38, I9:4, I9:6.

75 Luke 23:14.

76 Luke 23:24 (D-R).

77 Luke 23:24 (NRSV).

78 According to Mark I 5:27 (duo lēstas) and Matthew 27:38 (duo lēstai). What is crucial about the term lēstēs in Matthew and Mark is that it designates a public criminal (and a public enemy), rather than a man sentenced under Roman private law. The Vulgate's latrones is, thus, accurate-as can be inferred from Digesta 50.I6.I I 8. Modern English renderings tend to obscure this Greco-Roman legal sense of lēstēe-latro. Less specific is Luke 23:32, where Jesus is sent to the cross with "two other malefactors" (heteroi kakourgoi duo). In John I9:I8, Jesus is merely crucified between "two others" (allous duo)-although John I 8:40 specifies that Barabbas was a lèstès. The evangelists all position Jesus's cross in the middle of the group.

79 Aristotle, Poetics I453b-I454a, at I453b26-28: "The early [Greek] poets ... made the [tragic] agents act in knowledge and cognisance (eidotas kai gignōskontas), as Euripides [in recent times] made Medea kill her children. Alternatively, the agents can commit the terrible deed ... in ignorance." Translation taken, with slight modifications, from Aristotle, "Poetics"; Longinus, "On the Sublime"; Demetrius, "On Style," ed. with trans. Stephen Halliwell, F. Hamilton Fyfe, and Doreen Innes (Cambridge, MA: Harvard University Press, 1995), 74-77.

80 John 8:I2. Compare John I 2:34-36, 46. And for "Son of God," see John I9:7.

8 I John 3:I4-I 5 .

82 J. K. Elliott, The Apocryphal New Testament: A Collection of Apocryphal Christian Literature in an English Translation (Oxford: Clarendon Press, I993), I64-65. 
We have surviving variations on what appears to be a fourth-century Christian Acts of Pilate, ${ }^{83}$ which may have originally been put into circulation to neutralize a pagan Acts of Pilate that was "published under Emperor Maximin in 3 I I-I 2 for use against Christians." ${ }_{4}$ We have letters purportedly sent from Pilate to the emperors Tiberius ${ }^{85}$ and Claudius, and to the tetrarch Herod-and occasionally, letters in reply - all of which were authored by Christians. We even have a fictitious martyrdom of Pilate, in which he is put to death in Rome, but not before Jesus thunders out of the clouds to console his erstwhile judge: "All generations ... shall call you blessed, because in your governorship everything was fulfilled which the prophets foretold about me." 86 At the same time, the Pilate cycle celebrates his wife Procla (so named according to tradition), ${ }^{87}$ who "suffered many things ... in a dream" about Jesus and tried to prevent the crucifixion of "that just man" (according to Matthew 27). ${ }^{88}$

Agamben tarries for nine pages with this extra-canonical material, in what I take to be the apocryphal grouping of Pilate and Jesus $\left(\mathbb{S} \mathbb{S}_{3}-5\right)$. He convincingly divides this material into Christianizing and demonizing Pilate legends. According to the Christianizing legend, ${ }^{89}$ Pilate is "already a Christian in his own conscience" - the phrase, which Agamben quotes, is Tertullian's (iam pro sua conscientia christianus) ${ }^{90}$ - at the time of Jesus's trial. According to the demonizing legend, Pilate is dogged by "malignant and filthy spirits" who spectacularly defile his corpse after he is beheaded (or suicides) ${ }^{91}$ in Rome. ${ }^{92}$

Since this material is full of "curious imaginings," 93 Agamben's apocryphal grouping makes for lively reading. But in terms of substance, there is only one extra-canonical text that Agamben introduces in this grouping and then returns to in his exegetical grouping. When he introduces this text, he announces that he will return to it. 94 And conveniently, there is only a single passage of this text that he treats as significant.

The text in question is the recently mentioned fourth-century Christian Acts of Pilate. ${ }^{95}$ It is with this Acts that the "true and proper Pilate cycle ... begins," 96 according to Agamben, and the part of this Acts that intrigues him contains Pilate's "dialogue with Jesus on truth, which in the canonical gospels ends abruptly with Pilate's question" to Jesus, at John I 8:38: "What is truth?" In the Acts of Pilate-Agamben promises us in $\mathbb{S}_{3}$-this dialogue rather "continues and acquires a completely

83 It is unlikely that the Acts of Pilate cited by Justin Martyr at First Apology 35.48 corresponds to the Acts of Pilate we still possess. See, ibid., I64.

84 Ibid. (emphasis added).

85 Eusebius, Historia Ecclesiastica 2.2.I-3; The Ecclesiastical History, vol. I, ed. with trans. Kirsopp Lake (Cambridge, MA: Harvard University Press, I926), I IO-I7.

86 "Paradosis Pilati," Elliott, Apocryphal New Testament, 2 I I.

87 A feast of Saint Procla is still observed on October 27 in the Orthodox churches. Claude Laporte, Tous les saints de l'Orthodoxie (Vevey: Xenia, 2008), 554. Unaccountably, the date of October 26 is given at Agamben, Pilato $e$ Gesú, I6; Agamben, Pilate and Jesus, 8.

88 Matthew 27:19.

89 Winter, Trial of Jesus, 57-6I.

90 Tertullianus, Apologeticus adversus gentes, 21; Migne, Patrologia Latina, I:403.

9 I For the most credible report of Pilate's suicide, see Eusebius, Historia Ecclesiastica 2.7; The Ecclesiastical History, I:I 24-27. And for a critical review of this tradition, see Paul L. Maier, “The Fate of Pontius Pilate," Hermes 99, no. 3 (I97I): 362-7I, at 369-7I.

92 Agamben, Pilate and Jesus, I2; "Mors Pilati," Elliott, Apocryphal New Testament, 2 I6-I7.

93 S. G. F. Brandon, The Trial of Jesus of Nazareth (New York: Stein and Day, I968), I 54.

94 Agamben, Pilate and Jesus, 5 ("as we will see").

95 In Pilate and Jesus, Agamben prefers to call this Acts the Gospel of Nicodemus, a somewhat larger collection of extra-canonical texts within which the Acts of Pilate has been transmitted.

Agamben, Pilate and Jesus, 4 . 
different significance." 97 That is likely an overstatement. But it is no overstatement to say that the extra-canonical dialogue Agamben alludes to in $\mathbb{S}_{3}$, and then quotes in $\mathbb{7}_{7}$, contradicts the thesis of Pilate and Jesus.

Agamben's juridical thesis, which the apocryphal grouping is still preparing, is that Jesus's trial "does not conclude with a judgment." ${ }^{8}$ To buttress this thesis, Agamben insists that the Greek terms for judgment are not represented in the canonical trial narratives. He stresses this for the first time in $\$ 6$, at the outset of his exegetical grouping. "Judgment in Greek is krisis," we are informed; and then: "In the [trial] narrative of the evangelists the term does not appear." 99 This is inaccurate, as Agamben half-concedes in his first gloss. ${ }^{100}$ The Greek term for judgment is, in fact, represented in the Roman trial narrative of Luke, ${ }^{\text {IоI }}$ as it is in the predictions of a Judaic trial in Matthew and Mark ${ }^{102}$ and during the preparations for a Judaic trial in John. ${ }^{\mathrm{IO} 3}$ But what matters for us, here, is simply that Agamben does not want the term judgment to appear in the canonical trial narratives. This is because Agamben's Pilate has not judged, and cannot judge, his Jesus. ${ }^{\text {I04 }}$

Pilate, however, expressly judges Jesus in the extra-canonical dialogue that Agamben cites in $\mathbb{S}_{3}$, and then quotes in $\$ 7$. This is Agamben's report of that dialogue:

[T] he interrogation continues [after Pilate's question, "What is truth?"] with Jesus' reply: "Truth is from heaven," and with Pilate's new question: "Is there not truth upon the earth?" Jesus' response- "You see how those who tell the truth are judged by those who have authority on earth"-concludes the interrogation. ${ }^{105}$

Now, Agamben habitually gives the original Greek and Latin in parentheses, following critical or difficult terms in his sources. He decides not to do so here. But when Jesus responds to Pilate for the last time in the preceding exchange, he uses the term for judgment that Agamben denies finding in the canonical gospels. "You see," says Jesus, "how those who tell the truth are judged (krinontai)." Iо6

We see from this rebuke that Agamben's apocryphal Jesus is judged by his apocryphal Pilate. Moreover, this judgment is formally issued several chapters later in the Acts of Pilate, where-in a paragraph that Agamben prefers not to cite-Pilate says to Jesus,

Your nation has convicted (katēlegze) you of being a king. Therefore I have decreed (apephènamēn) that you should first be scourged according to the law of the pious [Roman] emperors, and then hanged on the cross in the garden where you were seized. And let Dysmas and Gestas, the two malefactors, be crucified with you. ${ }^{\text {107 }}$

\footnotetext{
97 Ibid., 5; Agamben, Pilato e Gesú, I 2.

98 Agamben, Pilate and Jesus, 47.

99 Ibid., I3; Agamben, Pilato e Gesú, 22-23.

Io० Agamben, Pilate and Jesus, 47-48.

IOI Luke 23:24 ("And Pilate gave sentence (epekrinen; Vulgate adiudicavit))."

IO2 Matthew 20:18; Mark I0:33.

I03 John 7:43-53; see especially John 7:5I ("Does our law judge (krinei) any man,” asks Jesus's night-visitor, Nicodemus, "unless it first hear him?”).

I04 Agamben, Pilate and Jesus, 52.

I05 Ibid., I9-20.

Iо6 Acta Pilati A 3.2; Constantin de Tischendorf, Evangelia Apocrypha, adhibitis plurimis codicibus Graecis et Latinis maximam partem nunc primum consultis ... (Leipzig: Hermann Mendelssohn, I876), 230.

107 Acta Pilati A 9.5; Elliott, Apocryphal New Testament, I76; Tischendorf, Evangelia Apocrypha, 244-45 (translation from Elliott, modified by reference to Tischendorf; emphasis added).
} 
Pilate's judgment, here, by no means contains purely canonical material. The names for the "malefactors" crucified with Jesus are extra-canonical (although the term itself, kakourgos, is likely taken over from Luke), ${ }^{108}$ and the idea of a crucifixion in Gethsemane is flagrantly counter-

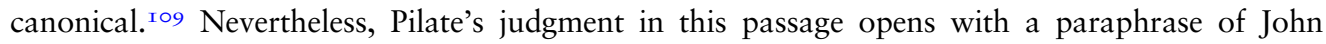
I 8:35 ("Your own nation and the chief priests have handed you over to me"), and his punitive decree is compatible with-and very likely, suggested by-the canonical narratives of the trial. This brings us to the exegetical grouping of Pilate and Jesus (\$\$ $\left.\$ 6-9, \mathrm{I}_{3}-\mathrm{I}_{4}\right)$.

\section{EXEGETICAL GROUPING: THE JUDGMENTS OF JESUS AND PILATE}

For Agamben, the truth of Jesus's interrogation by Pilate can be distilled into the single word: nonjudgment. Jesus is not judged by Pilate for the obscure reason that "Jesus could not actually be judged" - and this leads Agamben to make the obscurantist deduction that "there can truly be no judgment" until the Last Day. ${ }^{10}$ Pilate, in turn, is not judged because Agamben's Jesus practices nothing but a "critique of every judgment." without judgment," ${ }_{\mathrm{II} 2}$ which is also to say, "a simulacrum of a trial" (un simulacro di processo). ${ }^{\mathrm{II} 3}$

We can rapidly establish that the thesis of Jesus's non-judgment is contradicted by a series of texts in John - the gospel that Agamben cites in support of this thesis ${ }^{\mathrm{I} 4}-$ such as the following:

John 5:22: "The Father," Jesus testifies, "has committed all judgment to the Son." ${ }^{115}$

John 5:26-27: "The Father," he clarifies, "has given to [the Son] authority to execute judgment." $\mathrm{I} 16$

John 5:30: "I judge," says Jesus, "and my judgment is just." ${ }_{\text {II }}$

John 7:24: "Do not judge by appearances," he exhorts the multitudes, "but judge with right judgment."

John 8:26: "I have many things to say and to judge," he assures his disciples. ${ }^{119}$

John I2:3 I: "Now is the judgment of the world," he warns. ${ }^{\text {I20 }}$

John I6:II: "The prince of this world," Jesus declares in Jerusalem, "is already judged."

The critical passage here is John I 2:3 I, regarding "the judgment of the world" (krisis ... tou kosmou), since the evangelist interjects that Jesus said this "signifying the death he should die." ${ }^{222}$ In strictly exegetical terms, it is impossible to separate Jesus's death on a Roman cross

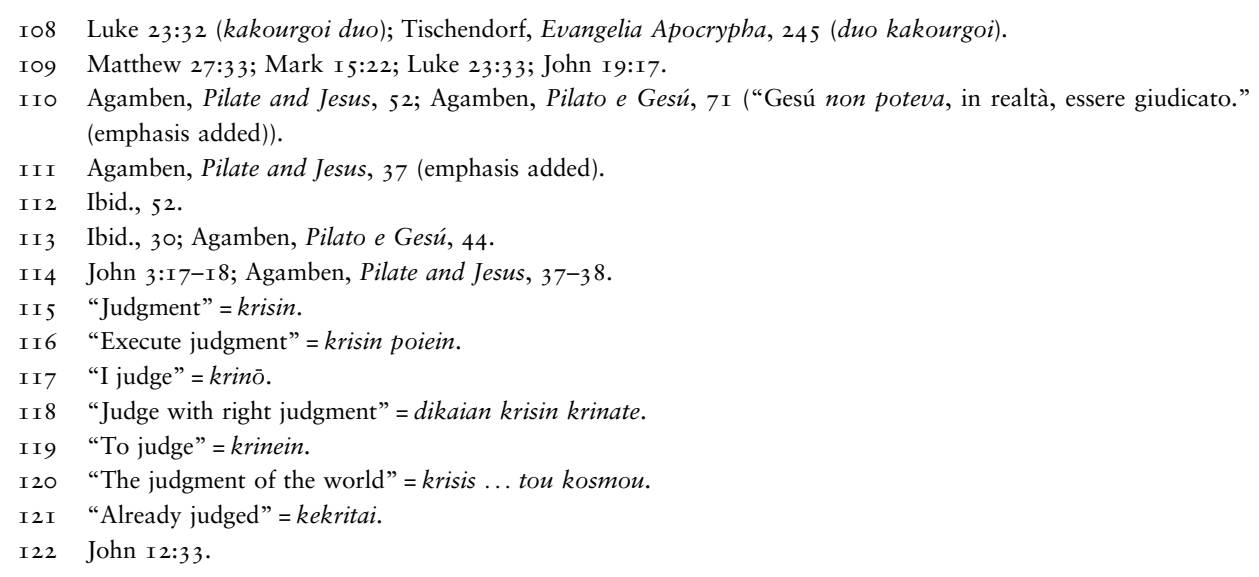


from a mystical judgment of Pilate-and indeed, of all terrestrial government - by Jesus. For in the gospel of John, at least, ${ }^{123}$ Jesus's cross is the place where the prince of this world is invisibly yet irreversibly judged and overcome. In other words, at the site of Jesus's punishment by Pilate (and the Sanhedrin), he accomplishes his judgment of Pilate (and the Sanhedrin).

Still, the supposed non-judgment of Jesus is of only momentary interest to Agamben. ${ }^{\mathrm{I} 24}$ In his exegetical grouping $\left(\mathbb{S} \mathbb{S} 6-9, \mathrm{I}_{3}-\mathrm{I} 4\right)$, he introduces the juridical thesis that shapes his theological and political groupings ( $\mathbb{S}$ IO-I2, I 5-I9) and preoccupies him in the glosses: the non-judgment of Pilate. This is the notion that serves, at once, as the fulcrum and base of Agamben's text: Jesus was crucified after "a trial without any judgment." ${ }_{225}$

At the close of the Roman phase of Jesus's trial, Pilate had "not handed down a sentence." 226 Agamben reiterates this claim frequently, and practically verbatim. Refusing to "pronounce a sentence," he writes in $\$ 7$, Pilate "limits himself to 'handing over' (paredōken) the accused to the Jews." 227 Pilate "does not give a verdict," he repeats in $\mathbb{S}_{I_{3}}$, but "limits himself to "handing over' Jesus" to be crucified. ${ }^{\mathrm{I} 28}$ And again, in his first gloss: the Roman prefect "did not pronounce his sentence," but "simply 'handed over' the accused to the Sanhedrin and the executioner." ${ }_{22}$

This is the place to point out that the juridical thesis of Pilate and Jesus is not original to Agamben. Already in the seventeenth century, Thomas Hobbes could write that "Pilate ... without

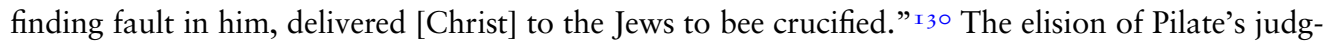
ment, here, signals a negation-and this reading of the trial of Jesus antedates Hobbes by at least I 300 years. There will be more on this subsequently.

Nearer to our purpose here is that the thesis of Pilate's non-judgment has maintained a presence in the critical literature since at least the appearance of Giovanni Rosadi’s Il processo di Gesú. ${ }^{\text {I3 I }}$ Consider the following:

I. "In reality," Rosadi asserts in I904, "the sentence was not pronounced [by Pilate]; the accused was simply handed over to his accusers." ${ }_{132}$ As we have seen, Agamben asserts the same-and in much the same wording-in Pilate and Jesus.

2. In a still indispensable 1935 essay, "Utilitas Crucis," E. J. Bickerman concedes that "none of the evangelists explicitly mentions the death warrant which Pilate issues. They all write that the procurator, wishing to satisfy the people's demands, 'handed over' Jesus to them, so that he

I 23 There is a rising trend in New Testament interpretation to see the gospels - and the evangel-in Roman imperial terms. For a recent analysis of Jesus's depiction as a "world ruler" in the Gospel of Mark, which persuasively situates this "in the context of Roman political ideology," see Adam Winn, "Tyrant or Servant? Roman Political Ideology and Mark I0.42-45," Journal for the Study of the New Testament, 36 no. 4 (2014): 325-52.

I24 Agamben, Pilate and Jesus, 37-38, 5I-52.

I25 Ibid., 5I; Agamben, Pilato e Gesú, 70.

I26 Agamben, Pilate and Jesus, 49; Agamben, Pilato e Gesú, 67.

I27 Agamben, Pilate and Jesus, 20-2I.

I 28 Ibid., 36.

I29 Ibid., 47 .

I30 Thomas Hobbes, Leviathan, vol. 3, The English and Latin Texts (ii), ed. Noel Malcolm (Oxford: Clarendon Press, 2012), 922-23.

I3 I Rosadi, Il processo di Gesú (Florence: G. C. Sansoni, I904).

I32 Giovanni Rosadi, Le Procès de Jésus, trans. Mena D’Albola (Paris: Perrin et C'ie, I908), 297 (author's translation from the French). I only learned of an English edition after this article was in press: Giovanni Rosadi, The Trial of Jesus, trans. Emil Reich (New York: Dodd, Mead, I905). (My thanks to Rupert Shortt for bringing this translation to my notice.) 
might be crucified.” 33 Crucially, however, Bickerman warns that "no one would infer from this that Paul or Justin [Martyr] ... ever forgot that juridically speaking, Jesus was condemned by the Roman procurator." 134

3. More darkly, a German jurist and Nazi Reichsjustizministerium officer, Wilhelm von Ammon, ${ }^{135}$ states flatly in 1953 , "Nowhere in the sources is there talk of a death sentence by the Roman governor Pontius Pilate against Jesus." ${ }^{36} 6$ Von Ammon of course had a sinister investment in the Gentile's non-judgment: it increases the Sanhedrin's guilt.

4. In his mid-century study, Der Prozess Jesu, Jozef Blinzler treats von Ammon's as a doctrinaire position. Introducing the problem of Pilate's judgment, Blinzler writes, "The evangelists do not explicitly say that Pilate pronounced a formal death sentence. Many researchers have concluded from this that his decision was not a verdict in the technical sense (kein Urteilsspruch im technischen Sinn)." 137 Agamben seems to half-recollect this passage of Der Prozess Jesu in one restatement of his own thesis. ${ }^{13} 8$ "A trial ... has taken place," Agamben concedes, but "there has not been any judgment in a technical sense (non vi è stato in senso tecnico alcun giudizio)." ${ } 39$

5. T. A. Burkill can still insist in the pages of Novum Testamentum, in the late twentieth century, that "in none of the canonical gospels does Pontius Pilate expressly affirm that Jesus was guilty of making kingly pretensions or of any other crime. ... [H]e simply orders an execution.” ${ }^{40}$

My task in the remainder of this section is to discredit this twentieth-century critical thesis-only, however, as Agamben argues it in Pilate and Jesus.

We can begin with Agamben's seemingly philological claim that there is no report of a Roman judgment in the gospels. "Judgment in Greek is krisis," he begins, before he then states that $(\alpha)$ : "In the [trial] narrative of the evangelists the term does not appear." ${ }_{\text {I } 4 \mathrm{I}}$

In writing $(\alpha)$, Agamben overlooks Matthew 20:I 8 and Mark 10:33, where Jesus predicts that the Sanhedrin will judge him-using an expression from the Greek stem that $(\alpha)$ excludes. ${ }^{142}$ More damaging is the fact that he takes no notice of several verses in the actual trial narratives of Matthew and Mark that state, in terms excluded by $(\alpha)$, that the Sanhedrin "judged" or "condemned" Jesus. ${ }^{\mathrm{I} 43}$ As it is written, then, $(\alpha)$ is false.

\footnotetext{
I33 Bickerman, "Utilitas Crucis,” 2:790-9I.

I34 Ibid., 2:738-39.

I 35 Incredibly, the topic of von Ammon's 1926 doctoral thesis is "the binding unlawful command." Wilhelm von Ammon, Der bindende rechtswidrige Befehl, Strafrechtliche Abhandlungen 217 (1926; repr. Frankfurt: Keip, 1977). After the Second World War, von Ammon was found guilty of crimes against humanity by the Nuremberg Tribunal. The prosecution cited his enforcement of the notorious Nacht und Nebel decree of December 7, I94I-which is to say, his enforcement of a "binding unlawful command."

I36 Wilhelm von Ammon, "Das Strafverfahren gegen Jesus von Nazareth," Nachrichten der Evangelisch-Lutherischen Kirche in Bayern 8 (1953): 69-72, at 7I, quoted in Josef Blinzler, "Der Entscheid des Pilatus-Exekutionsbefehl oder Todesurteil?," Münchener theologische Zeitschrift 5, no. 3 (I954): I7I-84, at I72.

I37 Blinzler, Prozess Jesu, I7 I-72. My thanks to A. S. Dusenbury for help with the translations of von Ammon's and Blinzler's statements.

I 38 Although he disapprovingly quotes Blinzler at Agamben, Pilate and Jesus, 38 .

I39 Ibid., 48-49; Agamben, Pilato e Gesú, 67.

I40 T. A. Burkill, "The Condemnation of Jesus: A Critique of Sherwin-White's Thesis," Novum Testamentum I2, no. 4 (I970): $32 \mathrm{I}-42$, at $328-29$.

I4 I Agamben, Pilate and Jesus, I3; Agamben, Pilato e Gesú, 23.

I42 Matthew 20:18; Mark I0:33.

I43 Matthew 26:66: apokrithentes; Matthew 27:3: katekrithē; Mark I4:64: katekrinan.
} 
But Agamben does not want $(\alpha)$ to be taken as it is written, since he has no interest in the Sanhedrin trial. ${ }^{\mathrm{I} 44}$ What he means by "the trial of Jesus" is merely the Roman phase of Jesus's trial, or what German specialists call the Pilatus-Prozess. Consequently, what Agamben materially claims in $(\alpha)$ is that krisis - the Greek term for judgment-never appears in the gospels' Roman trial narratives. Of this Agamben is confident: "On the fact that a sentence was not pronounced [by Pilate], the narrative of the Gospels does not seem to leave any doubt." ${ }^{4} 45$ Yet this also is false.

The Greek term for judgment is represented in the Roman trial narrative of Luke's gospel, in which we read that "Pilate gave sentence," ${ }_{46}$ or "gave his verdict." 147 The Lukan verb here is epikrinein (to judge), ${ }^{18} 8$ which the Vulgate renders with adiudicare (to judge). ${ }^{\mathrm{I}}{ }^{9}$ In his first gloss, Agamben tries to brush this off by writing that "the verb epikrino ... is never used in a trial-related sense." $5^{\circ}$ But what does he mean by "never"? He cannot mean that epikrinein never has a forensic sense in Greek literature-since the term already features in a discussion of verdicts in Plato's Laws. ${ }^{\text {5 }}{ }^{1}$ But neither can he mean that epikrinein never has a forensic sense in Judaic literaturesince the term announces a capital sentence in 2 Maccabees. ${ }^{152}$ Nor finally can he mean that epikrinein never has a forensic sense in the New Testament-since the term is only used to signal the conclusion of Jesus's Roman trial. For epikrinein is in fact a hapax legomenon in the New Testament. ${ }^{153}$ It only appears in Luke $23: 24,{ }^{\mathrm{I}} 54$ where it marks Pilate's judicial decree that Jesus should be crucified under the penal inscription: "This is the king of the Jews" (Luke 23:38).

In her fine monograph Pontius Pilate in History and Interpretation, Helen Bond catches the "technical nuance" of judgment in Luke's choice of epikrinein. This word shows Pilate in the act of issuing his capital sentence. ${ }^{\mathrm{I} 5}$ And this interpretation is put out of doubt by Luke 23:40, where one of the bandits crucified at Jesus's side says that he is dying "under the same sentence"

I44 A sentence written in the I970s still delivers a sharp rebuke to Agamben: "[T]he title 'Jesus and Pilate' does not do justice to the trial before Pilate, as it is set forth in the Fourth Gospel. The real title should be 'Jesus and the Jews before Pilate ....'" Severino Pancaro, The Law in the Fourth Gospel: The Torah and the Gospel, Moses and Jesus, Judaism and Christianity according to John (Leiden: E. J. Brill, 1975), 307.

I45 Agamben, Pilate and Jesus, 47.

I46 Luke 23:24 (D-R). For an identical modern rendering, see Bond, Pontius Pilate, I43.

I47 Luke 23:24 (NRSV).

I48 E. A. Sophocles, Greek Lexicon of the Roman and Byzantine Periods (Hildesheim: Georg Olms, I983), 503, s.v. "غ̇лíкрıбı૬": "judgment on anything” (followed by references to Strabo, Dioscorides, Plutarch, and Apollonius Dyscolus).

I49 Forcellini et al, Totius Latinitatis Lexicon, r:86, s.v. “adjudico.” The twentieth-century philologist Max Zerwick keeps adiudicavit here. Max Zerwick, Analysis Philologica Novi Testamenti Graeci, Scripta Pontificii Instituti Biblici 107 (Rome: Sumptibus Pontificii Instituti Biblici, I966), 205.

I 50 Agamben, Pilate and Jesus, 47.

I 5 I Plato, Leges $767 \mathrm{e}-768 \mathrm{~b}$, noting the occurrence of epikrinein at $768 \mathrm{a}$; Plato, Laws, 2 vols., ed. with trans. R. G. Bury (London: William Heinemann, I967), r:444-47. This judicial verb in Laws VI is a hapax in Plato's corpus, as in the New Testament. Leonard Brandwood, A Word Index to Plato (Leeds: W. S. Maney and Son, I976), 377, s.v. "غ̇лıкрíveıv."

I52 Henrico Stephanus [Henri Estienne], Thesaurus Graecae Linguae, 9 vols. (Graz: Akademische Druck- und

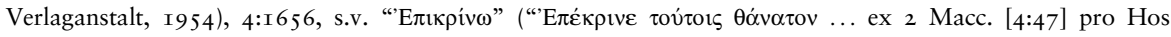
morte damnavit. Ad verbum, Adjudicavit his mortem.”).

I53 Paul Hoffman, Thomas Hieke, and Ulrich Bauer, Synoptic Concordance: A Greek Concordance to the First Three Gospels in Synoptic Arrangement, Statistically Evaluated, Including Occurrences in Acts, 4 vols.

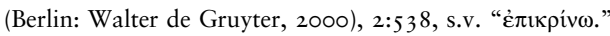

I 54 According to Hoffman, Hiecke, and Bauer, Synoptic Concordance, 2:538, and Aland, Synopsis Quattuor Evangeliorum, 479, the only Synoptic parallel to epikrinein in Luke 23:24 is boulomenos at Mark I 5:I 5 .

I 55 Bond, Pontius Pilate, I $58 \mathrm{n} 84$. 
as Jesus. ${ }^{156}$ The Greek term rendered "sentence" here is krima, meaning judgment, and hence, judicial sentence. ${ }^{157}$ Pilate's judgment of Jesus, which is issued in Luke 23:24, is unmistakably echoed by this bandit in Luke 23:40. Similarly, after Jesus's resurrection, one of his disciples laments that the Sanhedrin had "handed him over to be sentenced to death" (Luke 24:20). ${ }^{158}$ The disciple's term here is again krima, which can again only refer to Pilate's judgment. ${ }^{\mathrm{I} 9}$ It is of course to Pilate's tribunal that the Sanhedrin conducts Jesus. ${ }^{160}$

Our finding is thus that Luke not only reports a Roman sentence against Jesus, but three times references it: once during the Roman trial (23:24), once during the crucifixion (23:40), and once following the resurrection (24:20). Contra Agamben's ( $\alpha$ ), then, a Roman judgment undeniably occurs in Luke. But if Luke reports a Roman judgment, what of the other gospels? Is Pilate's judgment an instance of the gospels' disharmony? That is to say, is Pilate's judgment recorded in Luke, but counter-indicated in the other gospels?

This question carries us forward, since Agamben persistently links ( $\alpha$ ) to a distinct, and, for our purposes, final philological claim. As already quoted, Pilate "does not give a verdict" in Pilate and Jesus $(\alpha)$; instead, the Roman prefect "limits himself to 'handing over' Jesus" to be crucified $(\beta) .{ }^{16 I}$ While it is only Luke that defeats $(\alpha)$, all of the gospels appear to justify $(\beta)$. They all state that Pilate "handed over" Jesus to be crucified.

The substance of $(\beta)$ is Agamben's inference that this "handing over" is unconnected to Roman judgment. Unsurprisingly, this inference predates him in the critical literature by at least half a century. A Jesuit exegete, Joseph Bonsirven, concluded in 1952 that "Pilate did not pronounce a veritable sentence," on the grounds that in John I9:16, "we encounter the same word that is inscribed in the Synoptics: paredoken, 'he delivered up." " ${ }^{62}$ Bonsirven receives no mention in Pilate and Jesus.

But regardless of Agamben's sources, a complex New Testament thematic of "handing over" ${ }^{163}$ that is merely touched on by $(\beta)$ structures a transitional part of Agamben's exegetical grouping $(\mathbb{S} \mathbb{8 - 9})$ and the first part of his theological grouping $(\mathbb{S} 10)$. Having stressed in other works the etymological link between tradition (tradere) and betrayal (tradire), ${ }^{164}$ Agamben here exploits the same duplicity of the Greek verb paradidomi: Judas "betrays" Jesus in Gethsemane; Jesus "yields up" his spirit in death; the apostles "hand down" doctrines to the churches, and so on. All of these conveyances derive from the Greek verb paradidomi. Yet none of this concerns us, since the decisive formulation for our purposes is $(\beta)$ : Pilate "hands over" Jesus to be crucified.

As stated above, $(\beta)$ is lexically sound. The evangelists all use paradidomi to describe the moment when Pilate commits Jesus to a detachment of Roman troops-what Blinzler calls an Exekutionskommando ${ }^{165}$ - to be put to death:

I 56 "Under the same sentence" = en tōi autōi krimati; Vulgate = in eadem damnatione.

I 57 Max Zerwick and Mary Grosvenor, A Grammatical Analysis of the Greek New Testament, vol. I, GospelsActs, 3 rd rev. ed. (Rome: Biblical Institute Press, I974), 278 ("крí $\mu \alpha$ judgement, hence sentence.").

I 58 "Sentenced to death" = krima thanatou; Vulgate = in damnationem mortis.

I 59 Zerwick and Grosvenor, Grammatical Analysis, 28I.

I60 Matthew 27:I-2; Mark I 5:I; Luke 23:I; John I 8:28-29.

I6I Agamben, Pilate and Jesus, 36; Agamben, Pilato e Gesú, 53.

I62 Joseph Bonsirven, "Hora Talmudica: La notation chronologique de Jean I9, 4 aurait-elle un sens symbolique?," Biblica 33, no. 4 (I952): 5I I-I 5, at 5I3 (author's translation), quoted in Blinzler, "Entscheid des Pilatus," I72.

I63 This thematic is elegantly summarized at Pancaro, Law in the Fourth Gospel, 324-25.

I64 Agamben, Signature of All Things, Ioo-I.

I65 Blinzler, Prozess Jesu, I75. 
Matthew 27:26: "So Pilate released Barabbas for them; and after flogging Jesus, he handed him over (paredōken) to be crucified."

Mark I 5:I 5: "So Pilate, wishing to satisfy the crowd, released Barabbas for them; and after flogging Jesus, he handed him over (paredōken) to be crucified."

Luke 23:25: "He released the man they asked for, the one who had been put in prison for insurrection and murder [that is, Barabbas], and he handed over (paredōken) Jesus as they wished." John I9:I6: "Then Pilate handed over (paredōken) Jesus to them to be crucified."

But if $(\beta)$ is lexically correct, it is semantically incorrect. Or said differently: it is not the occurrence, but the sense of paradidomi in Jesus's Roman trial that $(\beta)$ misrepresents.

For Agamben implies with $(\alpha)$ that the language of "handing over" is detached from the machinery of judgment in the gospels. It is because of Pilate's non-judgment that he merely "hands over" Jesus, while this "handing over" is taken as evidence that Pilate has not sentenced Jesus. ${ }^{\mathrm{I} 66}$ The problem here is not only that Pilate sentences Jesus in Luke 23:24, immediately before he hands him over in Luke 23:25. The procedural logic of this is hard to miss: Pilate's "handing over" in verse 25 is consequent on his verdict in verse 24 . It is no less of a problem that the Sanhedrin's "handing over" of Jesus is consequent on its own judgment, and pursuant of a Roman judgment. ${ }^{167}$ We have already seen this in Luke 24:20, where the high-priestly court "handed Jesus over to be sentenced to death." What the Sanhedrin seeks, here, is a Roman "death sentence" (krima thanatou), and it is in order to obtain this sentence that they "hand Jesus over" (paredokan auton). Still, the most acute difficulty for Agamben is that "handing over" itself comes to serve as a juridical formula in the gospels. Far from encoding Pilate's non-judgment, that is to say, the occurrence of paradidomi in the gospels' trial accounts signals Pilate's judgment of Jesus.

It is necessary at this point to take distance from the trial narratives. For, long before Jesus is arrested by the Sanhedrin and handed over to Pontius Pilate, John the Baptist is seized by Herod Antipas. In the roughly parallel notices of John's arrest in Mark I and Matthew 4, the term used is paradidomi. ${ }^{168}$ In this way, the episode of John's arrest links the term paradidomi to wrongful imprisonment and death in the first chapters of the earliest gospels. ${ }^{169}$ The term's formal link to judgment is made no later than Matthew 5 and a related segment of Luke I 2 .

Matthew 5:25: "Come to terms quickly with your accuser," says Jesus, "or your accuser may hand you over (paradoii) to the judge, and the judge hand you over (paradōi) to the guard, ${ }^{170}$ and you will be thrown into prison.”

Luke I 2:58: "When you go with your accuser before a magistrate, on the way make an effort to settle the case, or you may be dragged before the judge, and the judge hand you over (paradōsei) to the officer, and the officer throw you into prison."

I66 Agamben, Pilate and Jesus, 47-48; Agamben, Pilato e Gesú, 65-66.

I67 Matthew 20:I8-I9, 27:I-2, 27:II-I3; Mark I0:33-34, I4:63-64, I5:I-4; Luke 22:71, 23:2; John I8:28-30, I 8:35. Especially important are Matthew 20:18-I9 $\approx$ Mark I0:33-34, where it is prophesied that Jerusalem's priestly courts will "condemn (katakrinousin) Jesus to death," and then "hand him over (paradōsousin) to the Gentiles ... to be crucified."

I68 Mark I:I4: paradothēnai; Matthew 4:I2: paredothē.

I69 Matthew IO:I7-25, 24:9; Mark I3:9-I3; Luke 2I:I 2-I 8; Acts 8:3, I2:I-5, etc.

I70 There is no second iteration of "hand you over" (se paradōi) in some manuscripts, but the sense remains in any case: Aland, Synopsis Quattuor Evangeliorum, 79. 
In both sayings, it is given that when a judge (kritēs) "hands over" a prisoner it is a juridical act, and that when he "hands over" a prisoner for punishment it indicates a prior sentence.

A rule of Bickerman's is apropos here: "We must decipher allusions to juridical facts which the sacred authors assumed their readers knew." ${ }^{17 \mathrm{I}}$ This is the situation with paradidomi in the gospels. The term's juridical significance is never stated in Matthew's gospel, for instance-yet without it, a parable in Matthew I 8 cannot be interpreted. Here, Jesus likens the divine Father to a human master who at first forgave a slave's debt and released him, but later summoned this slave and "handed him over (paredōken) to be tortured until he would pay." ${ }^{172}$ This parable's domestic court scenes simply assume the master's authority to judge his slaves. There is no reason for this authority, or this judgment, to be stated. Yet the parable ineluctably leads us to believe that this slave has been judged by his master, before being committed to the punishers, since his punishment is a type of the Last Judgment. ${ }^{173}$

It is only Paul who explicitly juridicalizes the term paradidōmi in the New Testament. When he writes to the Corinthian believers that he has "judged" (kekrika) one of their number, Paul then instructs the church to "deliver" (paradounai) the offender into the power of Satan, ${ }^{174}$ which is to say, into "the world." ${ }^{175}$ But if the juridical use of paradidomi is most explicit in this apostolic verdict, it is still definite in the gospels. The late Dominican lexicographer Ceslas Spicq was sensitive to this. As Spicq documents, paradidomi in Hellenistic papyri "often has the judicial meaning 'deliver to court or to prison." ${ }^{176} \mathrm{He}$ rightly observes that paradidōmi becomes "a technical term for Jesus's passion," and that in the gospels' trial narratives, it is "to be taken first in its legal and judicial sense.” ${ }^{177}$ It is precisely this juridical sense that Agamben, without justification, denies paradidōmi.

Contra Agamben's ( $\beta$ ), then, the occurrence of paradidomi before Jesus's crucifixion is a signal, in all the gospels, of Pilate's judgment-not his non-judgment. The Sanhedrin "hands Jesus over" to Pilate after ruling that he should be "sentenced to death." ${ }^{178}$ And Pilate "gives his verdict" before he "hands over" Jesus to be crucified. ${ }^{179}$ In both cases, the 'handing over' of Jesus is consequent on the sentencing of Jesus. Therefore, with ( $\beta)$, Agamben has cited a procedural Greek term as proof of a procedural breach in Jesus's trial. This fails to convince. In the gospels, "handing over" implies no absence of judgment. On the contrary, paradidomi is the language of courts, and the language of judgment.

\section{EXCURSUS: LACTANTIUS AND HUGO GROTIUS ON PILATE'S JUDGMENT}

Agamben holds that "the traditional interpretation of Jesus' trial ... must be revised" in light of Pilate and Jesus, ${ }^{\mathrm{I} 80}$ yet there is nothing new in his thesis that Pilate fails to pronounce a

\footnotetext{
I7I Bickerman, "Utilitas Crucis,” 2:778.

I72 Matthew I8:27, 34 .

I73 Matthew I 8:35 ("So my heavenly Father will also do to every one of you.").

I74 I Corinthians 5:I-5.

I75 I Corinthians 5:9-I3.

I76 Ceslas Spicq, Theological Lexicon of the New Testament, trans. and ed. James D. Ernest, 3 vols. (Peabody: Hendrickson, I994), 3:23.

I77 Ibid., 3:2 I.

I78 Luke 20:20, 24:20.

I79 Luke 23:24-25.

I80 Agamben, Pilate and Jesus, 48 .
} 
sentence. ${ }^{18 \mathrm{I}}$ On the contrary, this idea is archly traditional. Its twentieth-century bona fides have already been sketched, but the idea of Pilate's non-judgment originated in antiquity, and it attracted controversy throughout the early modern period. ${ }^{\mathrm{I} 82}$

Hugo Grotius's fabulously learned-and barbarously neglected-Annotations on the New Testament contains a compelling treatment of the question of Pilate's judgment. ${ }^{\mathrm{I} 83}$ In this ninevolume philological commentary, which has never been translated from the Latin, the preeminent international lawyer of the seventeenth century-who produced a Senecan tragedy ${ }^{184}$ of Jesus's trial and death, Christus Patiens, ${ }^{185}$ a year before he published his epoch-making treatise on the law of the seas, ${ }^{186}$ Mare Liberum-conclusively discredits the thesis of Pilate's non-judgment. And it is Grotius - not Agamben - who directs us to the Patristic text that long legitimized this thesis: Lactantius's Divine Institutes. ${ }^{187}$ Precisely because neither Grotius nor Lactantius figures in

I8I The same could be said of the central idea in Reza Aslan's Zealot: The Life and Times of Jesus of Nazareth (New York: Random House, 20I3) - a zealously marketed little book in which Aslan tries to sell us, as new, the oldest historical-critical interpretation of Jesus's life, message, and death.

Aslan's thesis first appeared in print in $\mathrm{I} 778$, when G. E. Lessing published a redacted and unfinished but truly seminal work by a German Hebraist who had passed away in I768: Hermann Samuel Reimarus, The Goal of Jesus and His Disciples, trans. George Wesley Buchanan (Leiden: E. J. Brill, 1970). If nothing else, Zealot is evidence that Reimarus is still survived by his Jesus.

Paul Winter's I96I assessment of the Reimarus hypothesis was, by all rights, conclusive: “Jesus of Nazareth was not in any sense of the word a $\lambda \eta \emptyset \tau$ ' $[$ [bandit or rebel]. He was no revolutionary, prompted by political ambitions for the power of government; he was a teacher who openly proclaimed his teaching." Winter, Trial of Jesus, 50 .

David Catchpole's statements, a decade later, are no less categorical: "Jesus was no Zealot, nor was he close to the Zealots. It is altogether in excess of the evidence to regard his movement and Zealotism as parallel or in sympathy with one another." In documentary terms, that is to say, "the 'political Jesus' theory is a failure." Catchpole, The Trial of Jesus: A Study in the Gospels and Jewish Historiography from 1770 to the Present Day, Studia Post-Biblica I 8 (Leiden: E. J. Brill, I97I), I26, 270. As Zealot's reception proves, however, the "political Jesus" theory is a lucrative failure.

I 82 I regret that time has not permitted me to track down a pair of extremely rare early modern tracts on Pilate's judgment:

I. Johannes Steller, Defensus Pontius Pilatus [or, according to one nineteenth-century catalogue entry: Pilatus liberatoris Jesu subsidio defensus], Dresden, I674.

2. Daniel Hartnaccius, Confutatio dissertationis perquam scandalose Joh. Stelleri, qua Pilatum defensum superiori anno turpissime prodidit, quæeque ad verbum huic opusculo prefixa est, Leipzig, 1676.

I83 Hugonis Grotii Annotationes in Novum Testamentum. Denuo emendatius editae, 9 vols. (Groningen: W. Zuidema, I826-I834) (All translations from this work are my own).

I 84 For Grotius's critical relation to the Senecan model, see James A. Parente, Jr., Religious Drama and the Humanist Tradition: Christian Theater in Germany and in the Netherlands, I500-I680 (New York: E. J. Brill, I987), $54-58$.

I 5 Hugonis Grotii Tragoedia Christus Patiens (Munich, I626); translated into English as Hugo Grotius, Christs Passion: A Tragedie with Annotations, trans. George Sandys (London: Printed by Iohn Leggatt, 1640).

I 86 Henk J. M. Nellen, Hugo Grotius: A Lifelong Struggle for Peace in Church and State, I583-I645, trans. J. C. Grayson (Boston: Brill, 2015), I02-I2, esp. I05-6.

I 87 Grotius, Annotationes in Novum Testamentum, 2:354. Whoever one takes to be the first orthodox proponent of Pilate's non-judgment (for example, St. Aristides), this tradition seems to be linked to a second-century docetic text, The Gospel of Peter. (Agamben appeals to this extra-canonical gospel to bolster his-unconvincing-interpretation of John I9:13 at Pilate and Jesus, 36.) In The Gospel of Peter, Pilate unyieldingly refuses to sentence Jesus. The task thus falls to Herod Antipas and "his judges" - in other words, to the Judaean authorities. It is unequivocally the tetrarch Herod, in The Gospel of Peter, who "commanded that the Lord should be taken 
Pilate and Jesus, it will be interesting to glance at Lactantius's denial, and Grotius's acceptance, of a Roman judgment by Pontius Pilate.

Lactantius was a fourth-century convert whose patron, significantly, was the Christianizing Roman emperor, Constantine I. Reflecting this fact, Constantine is addressed by name in the first line of Divine Institutes $4 .{ }^{188}$ Thus, it is to Constantine himself that Lactantius reports, in Divine Institutes 4.I0, that "in Tiberius' fifteenth year, in the consulship of the two Gemini, on 23 rd March, the Jews fastened Christ to the cross (Iudaei Christum cruci adfixerunt)." 89

It should require no comment that in this uniquely "Constantinian" version of the Passion, the Roman prefect is exculpated. Lactantius is writing "once the Pilates and Neros [have] themselves turned Christian," in Ernst Bloch's acid phrase. ${ }^{190}$ Moreover, he is writing at the court of the first emperor to have "turned Christian." In this setting, Pilate's non-judgment would be a highly politic supposition to make. But whatever his complex of motives: Lactantius imputes the crucifixion solely to the Jews. According to Lactantius, the death of Jesus is not chargeable to Rome or its laws.

And hereafter, in Divine Institutes 4, Israel's guilt is the recurring note-until, in 4.I8,

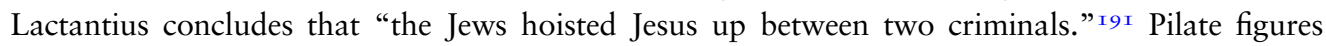
only briefly as the Roman official who questioned Jesus before "the Jews ... killed him." ${ }^{92}$ What exactly, on Lactantius's telling, is Pilate's role in the death of Jesus? It is certainly not judicial. Pilate indulged a Jerusalem lynch mob, but he "did not himself pronounce a sentence." Instead, Lactantius writes, he "handed Jesus over to the Jews." 193

Agamben's reprise of Divine Institutes 4.I 8 could hardly be more precise. He writes that Pilate "did not pronounce his sentence," but "simply 'handed over' the accused to the Sanhedrin." I94 This could serve as a passable translation of Lactantius's fourth-century Latin clauses: nec tamen ipse sententiam protulit, sed tradidit eum Iudaeis. ${ }^{195}$ Thus, without entering into the question of a Judaic crucifixion ${ }^{196}$ - a baseless rumor that Lactantius propagates, ${ }^{197}$ and that Agamben

off" and killed. Thus, after the resurrection, Pilate can unctuously protest that he is innocent of "the blood of the Son of God." Evangelium secundum Petrum I.I-2, I I Elliott, Apocryphal New Testament, I 54-57.

I88 Lactantius, Divinarum Institutionum 4.I.I; Lactantius, Institutions Divines. Livre 4, crit. ed. and annot. Pierre Monat (Paris: Les Éditions du Cerf, I992), 32.

I89 Lactantius, Divinarum Institutionum 4.I0.I 8; Lactantius, Institutions Divines, 90; Lactantius, Divine Institutes, trans. Anthony Bowen and Peter Garnsey (Liverpool: Liverpool University Press, 2003), 239 (translation modified).

I90 Bloch, Atheism in Christianity, I I9.

I9I Lactantius, Divinarum Institutionum 4.I8.6-9; Lactantius, Institutions Divines, I64; Lactantius, Divine Institutes, 257 (translation modified).

I92 Lactantius, Divinarum Institutionum 4.I8.4; Lactantius, Institutions Divines, I62; Lactantius, Divine Institutes, 257.

I93 Lactantius, Divinarum Institutionum 4.I 8.6; Lactantius, Institutions Divines, I64; Lactantius, Divine Institutes, 257 (translation modified).

I94 Agamben, Pilate and Jesus, 47.

I95 Lactantius, Divinarum Institutionum 4.I8.6; Lactantius, Institutions Divines, I64.

I96 Paul Winter traces this tradition back to the apology by Marcianus Aristides (a.k.a. St. Aristides), who claimed that Jesus was "crucified (pierced) by the Jews." Winter, Trial of Jesus, 58 . This apology bears the significant title, To the Emperor Hadrian Caesar from the Athenian Philosopher Aristides. Aristides is reputed to have delivered his oration at Athens, in Hadrian's presence, during the imperial visit of I25/26 C.E. Like Lactantius's Divine Institutes, then, Aristides's oration was addressed to a Roman emperor.

197 Lactantius, Divinarum Institutionum 4.I8.6-9; Lactantius, Institutions Divines, I64; Lactantius, Divine Institutes, 257 (translation modified). 
seems mistakenly to detect in Luke ${ }^{198}$ - we can conclude that the idea of Pilate's non-judgment is a Patristic one.

This returns us to Grotius-who not only cites Lactantius's opinion, but collects countertestimonies in his gloss on Matthew 27:26. The pagan Acts of Pilate, ${ }^{199}$ the Roman annalist Tacitus, ${ }^{200}$ the Roman jurist Paulus, ${ }^{201}$ and "Christ himself," ${ }^{202}$ differently testify to the fact that Pilate judged Jesus. What is more, Grotius notes that the "ancient Christians" - in contrast to a relative latecomer such as Lactantius-accepted that Jesus died under a Roman sentence. ${ }^{203}$ Grotius mines short passages from Ignatius in the second and Cyprian in the third century to support this claim. ${ }^{204}$ (I would add to this short catalogue Augustine in the early fifth century.) ${ }^{205}$ In this way Grotius proves, in the space of a single gloss, that Lactantius's opinion-and, mutatis mutandis, Agamben's - is a dissenting, and relatively late, Patristic opinion.

But Grotius is most impressive as an exegete. His commentaries on the Synoptic gospels were completed by I621,206 and this can be taken as the date after which it became frivolous to uphold the Lactantian tradition.

I98 In his second gloss, Agamben contrasts Matthew's account of the crucifixion - in which it is clearly "the soldiers of the governor" (27:27) who "led Jesus away to crucify him" (27:3 I) - with Luke's account. "Significantly," writes Agamben, "in Luke there is not a word (non si fa parola) about the soldiers." Agamben, Pilate and Jesus, 50-5I; Agamben, Pilato e Gesú, 69-70.

Agamben does not detail the precise significance that this supposed omission has for him-but in any case, there is no such omission. We find a reference to Pilate's troops at Luke 23:36 ("and the soldiers also mocked him"), and again at Luke 23:47 ("Now the centurion ... said, 'Indeed this was a just man'”).

The indistinctness of Luke's crucifixion narrative-he says only that "they crucified him" (Luke 23:33)-has nothing to do with the later myth of a Judaic crucifixion. Rather, it is accounted for by Luke's reprise of Jesus's death in Acts 4:24-28, where the parties culpable for the crucifixion are enumerated as "Herod and Pontius Pilate with the Gentiles and the people of Israel” (4:27). According to Luke, the whole of Roman Judaea killed Jesus. Grotius, Annotationes in Novum Testamentum, 2:354-55.

200 Ibid., 2:355. See Chapman and Schnabel, Trial and Crucifixion of Jesus, 196 ("Tacitus mentions Pontius Pilatus only because he wants to provide the historical context for the execution of Jesus ... which he presents as the result of a legally correct trial.”). And we should not overlook Josephus's reference to Pilate's sentence at Antiquitates Judaicae I 8.64 ("When Pilatus had condemned him (epitetimēkotos) to the cross.").

$20 \mathrm{I}$ Grotius argues that Jesus's cross signifies his conviction of the "crime of sedition" (crimen seditionis) at Annotationes in Novum Testamentum, 2:355.

202 Ibid. Grotius's appeal to Christ's saying is less uncritical than it may strike us. In his somewhat later text, Pilatus Judex, Willem van der Goes (Goesius) similarly contrasts the gospel text-in this case, Luke 23:24: "And Pilate gave sentence" - with Lactantius's argument, without further elaboration. When van der Goes writes that Jesus was crucified after being "convicted under a passed sentence (lata fententia)"; and notes that sedition was "the charge it pleased Pilate to judge, rather than blasphemy" (Hoc enim caufa damnationis magis placuit Pilatus, quam crimen blafphemice); van der Goes then enters a scriptural reference in the margins ("Luc 23. 24"), followed by a dismissive - because contrastive-citation of Lactantius (Aliter tamen Lact. 4 de vera fap. I 8 [= Divine Institutes 4.I 8]). Willem Goesius, Pilatus Judex, ad virum illuftrem Constantinum Hugenium, Equitem, Zulichemi Toparcham, \&c. (The Hague: Johannem Tongerloo, I68I), 62-63 (All translations from this work are the author's own). Grotius, Annotationes in Novum Testamentum, 2:355.

204 Ibid.

205 In his Homilies on the Gospel of John, Augustine vigorously rebuts the idea of Pilate's non-judgment. Augustinus, In Evangelium Ioannis Tractatus, I I4-17; Migne, Patrologia Latina, 35:1936-47.

Agamben takes note of this opposition in his first gloss, and has the temerity to charge Augustine with "doing violence" ( facendo violenza) to the syntax of John I9:I 6 in a Vetus Latina version (which is identical, here, to the Vulgate). Pilate and Jesus, 48; Agamben, Pilato e Gesú, 66-67. Unsurprisingly, Augustine's Latin is better than Agamben's.

206 Hugo Grotius, Meletius, sive De iis quae inter Christianos conveniunt Epistola, crit. ed. with trans. Guillaume H. M. Posthumus Meyjes (New York: E. J. Brill, I988), 64. 
Grotius begins by noting at Matthew 20:18-I9 that the Sanhedrin's judgment-predicted in Matthew 20 and issued in Matthew 26-is not a "judicial sentence" (sententia iudicis) in the fullest sense, but only a "pre-judgment" (praeiudicium). ${ }^{207}$ This is a crucial distinction of imperial legal practice in the first century, and the canonical accounts certainly stress that Jesus's nocturnal Sanhedrin trial-though it resulted in a "condemnation" (katakrima) of Jesus-was not held in open court (iudicium publicum). ${ }^{208}$ That the Sanhedrin's verdict only served as a praeiudicium is further reflected in the fact that Pilate can still urge the Judaic authorities, in John's narrative, to "take Jesus and judge him (krinate auton) according to your law."209

At the outset of Matthew 27, Grotius convincingly reconstructs the Sanhedrin's political calculation. A covert killing of Jesus would be scandalous; a lynching would be dangerous; therefore, Jesus must be sentenced to death in open court. Only the Roman prefect could preside over a iudicium publicum, however. ${ }^{2 \text { Io }}$ Therefore, Jesus had to be "delivered to Pontius Pilate." ${ }^{21 \mathrm{I}}$ This is of course what all the gospels relate. And when this "handing over" occurs, Grotius takes care to document the legal sense of paradidōmi, citing Jerome's corpus and Justinian's Digest. ${ }^{212}$

At Matthew 27:19 ("Pilate was sitting on the judgment seat"), Grotius specifies that the evangelist's use of a juridically significant phrase-in Greek, epi tou bèmatos; and in Latin, pro tribunali-prepares us for "the final interrogation during which Christ is sentenced to the cross." ${ }_{213}$ Then, at Matthew 27:26 ("The soldiers of the governor took Jesus"), Grotius evinces the aspects of Jesus's trial that fatally compromise the Lactantian tradition. ${ }^{214}$ They are numerous, says Grotius, but seven seem to be most salient.

I. Jesus's interrogation is conducted before Pilate's tribunal, ${ }^{215}$ which places him in the sanctum of Roman judgment (secretum iudicii locum). ${ }^{216}$

In his annotations on John's gospel, Grotius calls the tribunal a "dais" (locum excelsum), and emphasizes that no Roman judgment "could be uttered except from the dais (pro tribunali)." 217 In his I68 I treatise, Pilatus Judex, Willem van der Goes similarly remarks that "not even a child" could miss the significance of the site of Jesus's trial: he is subject to Roman judgment. ${ }^{218}$

2. The Sanhedrin disclaims the right to carry out a "capital sentence" (iudicium capitalium) in Jerusalem. ${ }^{219}$

207 Grotius, Annotationes in Novum Testamentum, 2:133.

208 Bickerman characterizes the procedural effect of the Sanhedrin's praeiudicium at "Utilitas Crucis," 2:750 ("Pilate was not obliged to be content with the results of the information supplied by the Sanhedrin, but to conduct a trial in depth.").

209 John I8:3I.

2 I0 Chapman and Schnabel, Trial and Crucifixion of Jesus, I6I.

2 I I Grotius, Annotationes in Novum Testamentum, 2:338.

2 I 2 Ibid.

2 I3 Ibid., 2:350.

2 I 4 Ibid., 2:354. I have reordered Grotius's list, which is neither logical nor chronological.

2 I 5 Ibid.

2 I6 Ibid., 2:350.

2 I7 Ibid., 4:263. Also relevant here is Grotius's remark on I Timothy 6:I3 ("Christ Jesus ... in his testimony before Pontius Pilate"), which draws out the juridical sense of the proto-creedal formula, "before Pontius Pilate" (epi Pontiou Pilatou). "Taken in its proper sense," Grotius specifies, "epi denotes standing before a judge." Ibid., 7:270.

2 I 8 Goesius, Pilatus Judex, 69.

219 Grotius, Annotationes in Novum Testamentum, 2:354. 
This has been controverted in much of the modern literature, not least due to passages in the gospels and Acts. ${ }^{20}$ Still, it is hard to deny that a Roman prefect reserved supreme jurisdictionthat is to say, "unlimited executive and legal authority, including the ius gladii" ${ }^{22}-$ in the Roman province that he governed. ${ }^{22}$ And according to the most recent treatment of the question, Philo's writings and the gospels only "lend support to the view that the Jews might carry out vigilante execution ... without due court procedure." ${ }^{223}$ It is precisely this last type of executionnamely, lynching - that the Sanhedrin ruled to be excessively dangerous in Jesus's case. ${ }^{224}$

3. All the clamor before Pilate tends towards a juridical conclusion-in Grotius's words, "that Pilate condemn Jesus with his own voice" (ut Pilatus sua voce Iesum damnaret).225 Pilate's verdict is a necessary precursor to Jesus's crucifixion.

4. Despite his reluctance to issue a verdict, and his repeated declarations of Jesus's innocence, Pilate ultimately yields to the crowd by handing down a Roman sentence (sententiam obsequium commodavit).226

There can be absolutely no equivocation on this point. Grotius clarifies this in his lexical note on Luke 23:24 ("Pilate gave sentence"). "Epikrinein means nothing other," writes Grotius, "than to render a judicial sentence (iudicando decernere)." 227 And in his gloss on Luke 24:20 ("our chief priests ... handed Jesus over to be sentenced to death"), he reiterates that only Pilate's "judgment" (sententia) could have effectuated the Sanhedrin's pre-judgment. ${ }^{228}$

5. Only Roman troops were authorized to carry out a crucifixion. ${ }^{229}$ Grotius returns to this point in his comment on Matthew 27:3 I ("Then they led him away to crucify him"), quoting Tacitus, Suetonius, and Tertullian to the effect that "the Romans [always] used soldiers to exact this punishment." ${ }_{230}$

6. The cross, according to Grotius, is "a punishment distinctive to Roman law, and foreign to the laws of the Jews." ${ }^{23}$ I

Grotius's first clause is uncontentious, and his second clause is vindicated by Gunnar Samuelsson's recent monograph, Crucifixion in Antiquity, which concludes that there is no extant record of a Judaic crucifixion. ${ }^{232}$ Bickerman reached the same conclusion in "Utilitas Crucis," a decade before the Dead Sea Scrolls came to light. ${ }^{233}$ The only forms of execution that have Mishnaic sanction are stoning, burning, beheading, and strangling. ${ }^{234}$ (Thus, Jesus reproaches the Holy City for having "stoned" (lithobolousa) its prophets. $)^{235}$

220 See, for instance, John I0:3 I; Acts 4:56-59.

22 I Chapman and Schnabel, Trial and Crucifixion of Jesus, I55-56.

222 See Bickerman, "Utilitas Crucis," 2:743.

223 Per Jarle Bekken, The Lawsuit Motif in John's Gospel from New Perspectives: Jesus Christ, Crucified Criminal and Emperor of the World, Supplements to Novum Testamentum I 58 (Leiden: Brill, 201 5), 23-70, at 69.

224 Grotius, Annotationes in Novum Testamentum, 2:338.

225 Ibid., 2:354.

226 Ibid.

227 Ibid., 3:476.

228 Ibid., 3:497.

229 Ibid., 2:354.

230 Ibid., 2:357.

23 I Ibid., 2:354.

232 Samuelsson, Crucifixion in Antiquity, 235-36 ("The common assumption that the Dead Sea Scrolls contain references to crucifixion [under Judaic law] cannot be upheld.”).

233 Bickerman, "Utilitas Crucis," 2:784.

234 Winter, Trial of Jesus, 69-74, especially 70 (citing Mishnah Sanhedrin 7.I).

235 Matthew 23:37 = Luke 13:34. 
"According to the Hebrew law," Bickerman observes, "blasphemers were to be stonedand Jesus was crucified." Like Grotius, he makes the necessary inference: "Juridically speaking, Jesus was condemned by the Roman procurator." ${ }^{236}$

7. Pilate himself dictates the inscription which is affixed to Jesus's cross: Iesus Nazarenus Rex Iudaeorum. ${ }^{237}$

Grotius takes seriously the juridical symbolism of this inscription in his comment on Matthew 27:37 ("Over his head they put the charge against him"). Suetonius and Tertullian use the Latin term titulus for this type of inscription (and as Paul Winter points out in his 196I monograph, On the Trial of Jesus, "this technical term actually occurs in John I9:19"), ${ }^{238}$ while the Roman consul Dio Cassius provides Grotius with a definition of such a script: it consists of "words setting out the crime for which a man is dying" (literas causam mortis indicantes). ${ }^{239}$ That Pilate dictates Jesus's inscription can therefore only mean that Pilate had himself declared, pro tribunali, the crime for which Jesus would die.

Legal historian Robert Besnier argues in the same way to Grotius-that is, from Jesus's titulus to Pilate's judgment-in the Tijdschrift voor Rechtsgeschiedenis. "The proof of the existence of a conviction by Pilate," writes Besnier, "is furnished by the fact that on Jesus' cross there is a titulus." ${ }^{40}$ And Winter concurs: "The charge on which he was executed, is stated explicitly in the titulus on the cross." ${ }^{24 \mathrm{I}}$

In short, the penal inscription affixed to Jesus's cross proves Pilate's judgment.. ${ }^{242}$

Grotius alludes to "other circumstances" that belie the Lactantian tradition ${ }^{243}$ - the tradition that Agamben represents-but he considers it unnecessary to go into them. Surely it is.

\section{CONCLUSION}

At the core of Pilate and Jesus is the ancient and discredited notion that the Roman trial of Jesus is "a trial without a judgment." 244 Agamben's whole text revolves upon this Lactantian interpretation of the gospels, and he even appears willing to stake a new general theory of judgment on its validity:

Jesus could not actually be judged. Just as the law cannot justify anyone, so also can it judge no one.... There can truly be no judgment, because it has always already happened. ... The trial of Jesus-every trial-begins when judgment has already happened. The judge can only hand over the accused to the executioner; he cannot judge him. (Il giudice può soltanto consegnare l'accusato al carnefice, non può giudicarlo. $)^{245}$

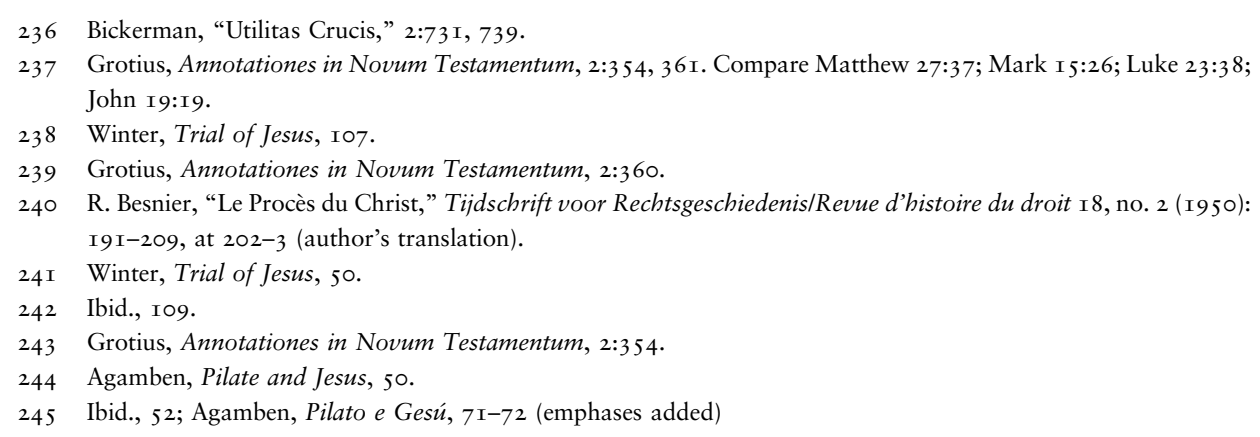


The most obvious objection to this theory is not-as Agamben suggests-that it constitutes "the most severe objection that can be raised against the juridical order (il diritto)." ${ }^{246}$ Rather, this theory must be discounted because it blurs out the most basic juridical phenomenon. And for this phenomenon, conveniently, we can cite Pontius Pilate. "Do you not know that I have the power to crucify you," he asks a taciturn Jesus, "and I have power to release you (apolusai se)?" ${ }^{247}$ It is this duplicity that constitutes the task and power of the judge. The judge is precisely not one who "can only hand over the accused."

We glimpse this duplicity again in Acts 3:I3, which states that Pilate originally "judged" that he should not hand over the accused to be crucified. When Jesus stood "before the face of Pilate," Peter says here, "he judged (krinantos) that Jesus should be released (apoluein)." Like inculpation, exculpation is a work of judgment. Of course, Jesus's trial did not end with that judgment; but it did end with a Roman judgment.

It is Jesus's crucifixion, and not Pilate's judgment, that inaugurates the mystery of Christian faith. Yet Pilate figures in the gospels and Acts, the apostolic letters, and the most primitive Christian formularies for the ineliminable reason that Jesus could not have been crucified without his sentence. ${ }^{248}$ It is only because Agamben denies a Roman sentence that he is mystified by Pilate's presence in the Creed. For the confession of Pontius Pilate is not a mystery. It is precisely in the office of Jesus's judge that Christians recollect him.

Agamben undertakes in Pilate and Jesus to "carefully evaluate every detail" of Jesus's Roman trial. ${ }^{249}$ In evidentiary terms, he fails. After his misleading opening sections on the Creed, Agamben takes up a fourth-century Christian Acts of Pilate. He misses the fact that this Acts shows Pilate sentencing Jesus. Agamben's exegetical sections follow, and give the impression of originality. But in them he reintroduces a doctrinaire twentieth-century thesis that at the close of Jesus's Roman trial-as Giovanni Rosadi put it in 1904- "the sentence was not pronounced; the accused was simply handed over to his accusers." ${ }^{\circ}{ }^{\circ}$ This thesis proves to be doubly erroneous. In the first place, because Luke reports the pronunciation of a Roman sentence. And in the second place, because in all the gospels, Pilate's "handing over" signals a punitive juridical act.

There is a formidable irony behind all of this. For in the last pages of Pilate and Jesus, Agamben revisits the topic of his first pages: Pilate's appearance in the creed of $38 \mathrm{I}$. Having aestheticized the Roman prefect in $\$ 2$, Agamben prefers to politicize him in his penultimate gloss. He writes here that "the name of Pilate was included in the Constantinopolitan Symbolon" as a "theological justification of imperial power and of the alliance that the church had concluded" with Rome in the fourth century. ${ }^{25}$

In historical terms, this is pure insinuation. Pilate is already named in formulaic texts of the canonical Acts and I Timothy. But the irony, here, is that it is not the Creed's solemn insistence upon Pilate's judgment that subserved a fourth-century "alliance" of church and empire. To the contrary, it is Lactantius's interpretation of the Passion-now Agamben's-that flattered a newly Christianized Roman imperium. Pilate's non-judgment is the Constantinian line. Thus, even while he is indicting the Council of Constantinople-and throughout Pilate and Jesus-it is Agamben who is unconsciously reproducing a theological justification of imperial power.

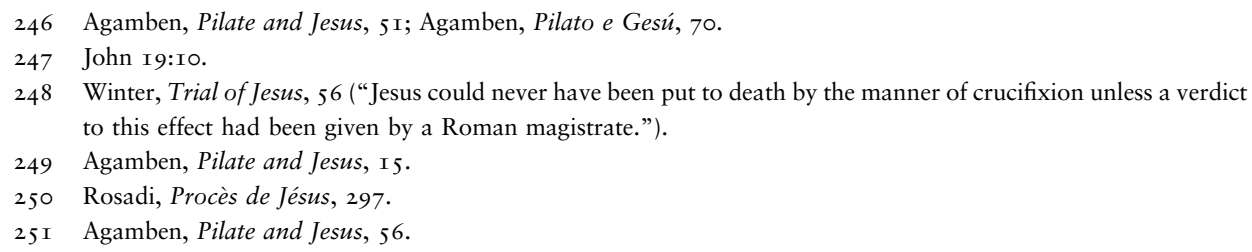

